\title{
Intercellular C-signaling in Myxococcus xanthus involves a branched signal transduction pathway
}

\author{
Lotte Søgaard-Andersen, ${ }^{1}$ Frank J. Slack, ${ }^{1,2}$ Harvey Kimsey, ${ }^{3}$ and Dale Kaiser ${ }^{4}$ \\ Department of Biochemistry, Stanford University School of Medicine, Stanford, California, 94305 USA
}

\begin{abstract}
C-factor, the product of the $\operatorname{csg} A$ gene, is a cell-surface associated short-range intercellular signaling protein in Myxococcus xanthus. C-factor is required for at least four responses during starvation-induced fruiting body morphogenesis: rippling, aggregation, sporulation, and full expression of the $\operatorname{csg} A$ gene, all of which fail in a $\operatorname{csg} A$ mutant. To analyze the C-factor signaling pathway, eight Tn5 lac insertion mutants that began but failed to complete fruiting body aggregation were characterized. Seven of the insertions identified genes whose products function in the $\operatorname{csg} A$ signaling pathway. The seven mutants were differentially deficient in the $C$-factor responses, and could be divided into two classes on the basis of those differences. On one hand, the four mutants in class I were deficient in rippling and aggregation, but sporulated and produced $C$-factor at wild-type levels. The Tn5 lac insertions in the class I mutants mapped to the frz locus, which encodes a signal transduction system that controls the frequency of single cell reversals. On the other hand, mutants carrying any of the three closely linked class II Tn5 lac insertions had deficiencies in all four C-factor responses. Because the sporulation defect in the class II mutants is cell autonomous, the data suggest that the primary defect in these mutants is an inability to respond to the C-factor signal. All the data can be explained by a model in which the first part of the $\mathrm{C}$-factor signaling pathway is common to all four $\mathrm{C}$-factor-dependent responses. The genes identified by the class II insertions would function in the common part. Downstream of class II, the pathway branches. One branch includes the frz genes and leads to aggregation and rippling; the second branch leads to sporulation and controls the level of $\operatorname{csg} A$ gene expression. This model was confirmed in epistasis tests with characterized frz mutations, a $\operatorname{csg} A$ null mutation, and a class II mutation.
\end{abstract}

[Key Words: Intercellular signaling; epistasis tests; C-factor signaling; prokaryotic development; prokaryotic differentiation; starvation]

Received July 7, 1995; revised version accepted January 29, 1996.

Communication between cells by means of extracellular signals is important for morphogenesis and differentiation in multicellular organisms. In several systems extracellular signal molecules elicit two different responses. For example, in Dictyostelium discoideum, cAMP elicits two temporally separated responses, aggregation and sporulation (Gross 1994), and in Drosophila melanogaster wingless signaling results in simultaneous changes in gene expression and cell adhesiveness (Arias 1994). This raises the question of how the signal transduction pathways are structured to provide qualitatively different responses to one signal molecule.

Myxococcus xanthus cells undergo a multicellular developmental program in response to nutrient limitation (Shimkets 1990; Kim et al. 1992). Within 4 to $8 \mathrm{hr}$, the

\footnotetext{
1 These authors contributed equally to the work presented.

Present addresses: ${ }^{2}$ Department of Genetics, Harvard Medical School Massachusetts General Hospital, Wellman 8, Boston, Massachusetts, 02114 USA; ${ }^{3}$ Department of Molecular Biology and Microbiology, Tufts University School of Medicine, Boston, Massachusetts, 02111 USA

${ }^{4}$ Corresponding author.
}

cells begin to aggregate by gliding to foci where $10^{5}$ cells build a structure known as a fruiting body. Within a fruiting body, the rod-shaped cells differentiate into spherical, environmentally resistant spores. Aggregation and sporulation are temporally separated, and sporulation in wild-type cells does not occur until cell movements have led to the assembly of a structure with the external form of a fruiting body. The earliest phases of aggregation are often accompanied by ripple formation. Ripples consist of a series of equally spaced ridges of cells that move in a coordinated fashion like travelling waves on a surface (Shimkets and Kaiser 1982a). Rippling is not obligatory for the construction of fruiting bodies but generally accompanies this process (Shimkets 1990). Several different extracellular signals are required to coordinate fruiting body morphogenesis (Kaiser and Losick 1993).

One of these signals is the cell-surface associated protein C-factor, which is the product of the $\operatorname{csg} A$ gene (Hagen and Shimkets 1990; Kim and Kaiser 1990a,c; Shimkets and Rafiee 1990). In $\operatorname{csg} A$ mutants, the developmental process arrests early in the aggregation phase, 
ripples are not formed, and sporulation is severely impaired (Shimkets and Kaiser 1982a). $\operatorname{csg} A$ mutants also exhibit altered developmental gene expression as monitored by the expression of a panel of transcriptional fusions to the lac genes in Tn5 lac. Expression from Tn5 lac fusions that are normally expressed at $6 \mathrm{hr}$ or later into development is abolished partially or completely in $\operatorname{csg} A$ mutants (Kroos and Kaiser 1987). One of the C-factor-dependent genes is $\operatorname{csg} A$ itself and full expression of $\operatorname{csg} A$ requires C-factor signaling (Kim and Kaiser 1991). Aggregation, sporulation, and developmental gene expression are rescued by codevelopment of $\operatorname{csg} A$ cells with wild-type cells (Shimkets et al. 1983; Kim and Kaiser 1990a) or by the addition of purified C-factor (Kim and Kaiser 1990a,c). Addition of C-factor to nonmotile cells induces sporulation in the absence of aggregation (Kim and Kaiser 1991). These observations suggest that $\mathrm{C}$-factor can induce directly the two temporally separated morphogenetic processes aggregation and sporulation in fruiting body formation (Kim and Kaiser 1991).

Rescue of $\operatorname{csg} A$ cells by wild-type cells requires contact between the $\operatorname{csg} A$ and the $\operatorname{csg} A^{+}$cells (Kim and Kaiser 1990a) and active motility in both cell types (Kroos et al. 1988; Kim and Kaiser 1990b), suggesting that cells are brought into the proper arrangements for efficient transmission of the C-signal by their own movements (Kim and Kaiser 1990d). This observation and the finding that a lower concentration of $\mathrm{C}$-factor is required for aggregation than for sporulation (Kim and Kaiser 1991; Li et al. 1992) has led to the hypothesis that $\mathrm{C}$-factor coordinates these two processes (Kim and Kaiser 1991; Li et al. 1992). This coordination would rely on two positive feedback loops: (1) increased $\operatorname{csg} A$ expression in response to $\mathrm{C}$-factor signaling, and (2) increased $\mathrm{C}$-factor signaling attributable to close and ordered packing of cells in the fruiting body resulting from the C-factor-induced aggregation (Kim and Kaiser 1990d, 1991; Sager and Kaiser 1993).

The molecular mechanism by which the C-signal is transmitted between cells is not yet known. Likewise, little is known about the intracellular transduction of the $\mathrm{C}$-factor signal once it is received by a cell. The aim of this work is to begin to define the C-signal transduction pathway. Here, seven mutants that interrupt this pathway are described. On the basis of their properties and the properties of certain double mutants, we suggest that the signal transduction pathway has an upstream segment common to all four C-factor-dependent activities. Downstream of this common part, the pathway branches. One branch leads to the motility responses and a second branch to sporulation and to control of gene expression, including $\operatorname{csg} A$ itself.

\section{Results}

Isolation of Tn5 lac insertion mutants blocked in the aggregation phase

After $24 \mathrm{hr}$ of normal development, $M$. xanthus cells have aggregated and constructed well-formed and steep- sided fruiting bodies, whereas a $\operatorname{csg} A$ mutant has formed loose, irregular aggregates (Fig. 1A). To isolate mutations that may interrupt the earliest steps in the C-factor signal transduction pathway, mutants that arrested their development within the aggregation process $\left(\mathrm{Agg}^{-} \mathrm{mu}-\right.$ tants) were sought beginning with a set of $42 \operatorname{Tn} 5$ lac insertion mutants that all had a developmental defect. This set of mutants was retrieved originally from a collection of 10,000 Tn5 lac insertion mutants that were isolated in the fully motile strain DK1622, which serves as the standard or wild type for these studies.

Approximately half of the 42 developmental mutants were disabled in either adventurous (A) motility or in social (S) motility during vegetative growth (data not shown), affirming the strong connection between development and motility in $M$. xanthus (Shimkets 1990). Because $\operatorname{csg} A$ strains exhibit normal vegetative motility (i.e., are $\mathrm{A}^{+} \mathrm{S}^{+}$), mutants found to be disabled in $\mathrm{A}$ or $\mathrm{S}$ motility were not studied as part of this work. By monitoring the development of the remaining mutants on TPM starvation agar, the stage at which aggregation was altered in each of these mutants could be identified. Seven of the mutants exhibited a particular $\mathrm{Agg}^{-}$phenotype in which they initiated aggregation without completing it. The remaining mutants showed no aggregation, or completed aggregation but formed abnormal fruiting bodies, or completed their development more slowly than wild type (data not shown). The seven Agg ${ }^{-}$ mutants and a previously isolated $\mathrm{Tn} 5$ lac insertion mutant, $\Omega 4491$ in DK5285, which also exhibits an $\mathrm{Agg}^{-}$ phenotype, were chosen for further study (Kroos et al. 1986, 1990; Kroos and Kaiser 1987). To construct an isogenic set of strains for detailed comparisons, the Tn5 lac insertions in the newly isolated $\mathrm{Agg}^{-}$mutants were crossed back into a wild-type strain, DK1622. In each case, the phenotype of the transductants was similar to the original mutant strain carrying the Tn5 lac insertion (data not shown), indicating that the $\mathrm{Agg}^{-}$phenotype was caused by the Tn 5 lac insertion. All subsequent experiments were conducted with the backcrossed strains.

\section{Classification of the Agg ${ }^{-}$mutants according to their capacity to perform C-factor-dependent activities}

Wild-type strains as well as strains carrying mutations in the A-signaling $(a s g)$, D-signaling $(d s g)$, or B-signaling (bsg) pathways, are able to form ripples early in development when placed on low nutrient agar (Shimkets and Kaiser 1982a,b). $\operatorname{csg} A$ mutants are unable to ripple (Shimkets and Kaiser 1982a), presumably because C-factor is required to stimulate cell reversals required for rippling (Sager and Kaiser 1994). The ability of the $\mathrm{Agg}^{-}$ mutants to ripple was tested on CF agar (see Materials and methods) and found to be abolished in all of them (data not shown). As rippling is considered a C-factordependent developmental event, these results suggest that the Tn5 lac mutations may disrupt C-signaling.

Rippling appears to require the activity of both the S and A motility systems (Shimkets and Kaiser 1982a). Likewise, $\mathrm{C}$-factor signaling requires that the cells are 
Figure 1. Aggregation phenotype of Tn5 lac insertion mutants. (A) Aggregation phenotype in $\operatorname{csg} A^{+}$background. For comparison, the aggregation phenotypes of wild-type and $\operatorname{csg} A$ strains have been included. The $\operatorname{csg} A$ allele used throughout is csgA::Tn5-132 2LS205. (B) Aggregation phenotypes of $\operatorname{Tn} 5$ lac insertion mutants in a $\operatorname{csg} A$ background. (C) Aggregation phenotype at low magnification in $\operatorname{csg} A^{+}$ and in $\operatorname{csg} A^{-}$backgrounds; strains in the upper row carry the $\operatorname{Tn} 5$ lac insertions in a $\operatorname{csg} A^{+}$background and those in the lower row in a $\operatorname{csg} A^{-}$background. In all experiments $A-C, 20 \mu$ l of a cell suspension with a calculated density of 1000 Klett units/ $\mathrm{ml}$ in TPM buffer was placed on a TPM agar, and the cells allowed to develop for $24 \mathrm{hr}$. The Tn5 lac insertion present in a strain is indicated above each panel. Strains: $(A)$ DK1622 (wild type), DK11016

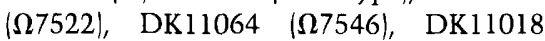

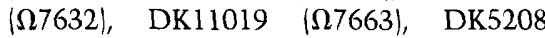
$(\operatorname{csg} A), \quad$ DK5285 ( 24491$), \quad$ DK1 1063

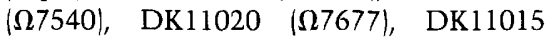
$(\Omega 7516) ;(B)$ DK11050 ( $\Omega 7522)$, DK11051 $(\Omega 7546), \quad$ DK $11053(\Omega 7632)$, DK 11054

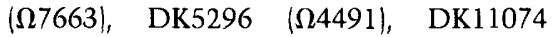

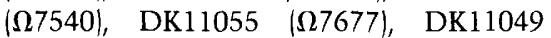
$(\Omega 7516)$; $C$ ) DK1622 (wild type), DK1 1016

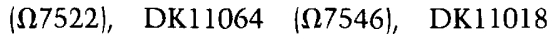

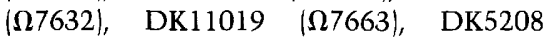
$(\operatorname{csg} A), \mathrm{DK} 11050(\Omega 7522, \operatorname{csg} A), \mathrm{DK} 11051$

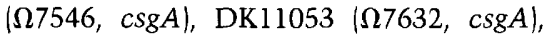
DK1 $1054(\Omega 7663, \operatorname{csg} A)$. The complete genotype of these strains is given in Table 7 . $(A, B)$ Bar, $1 \mathrm{~mm} ;(C)$ bar, $2 \mathrm{~mm}$.
A
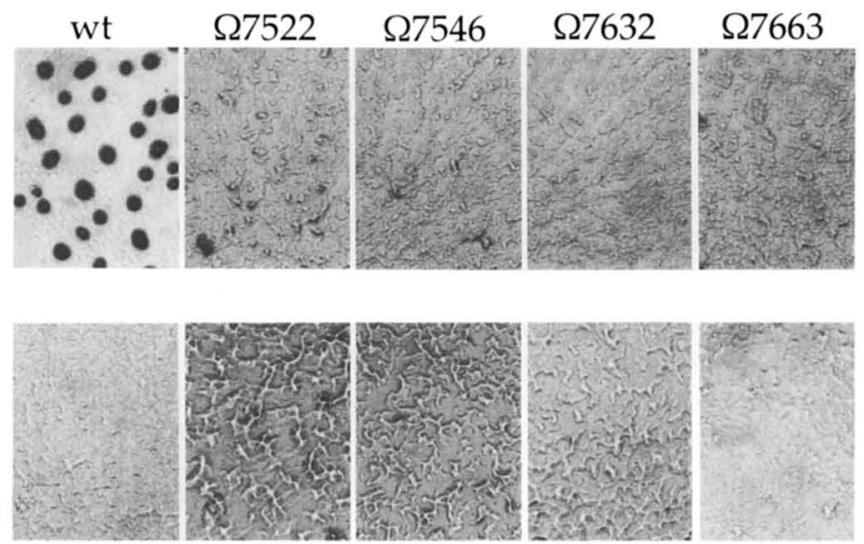

B

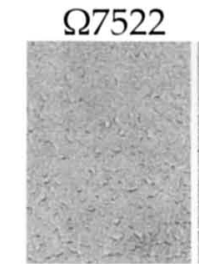

$\Omega 7546$

$\Omega 7632$

$\Omega 7663$

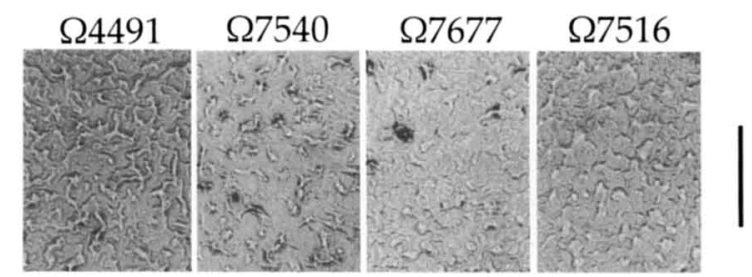

C

$\operatorname{csg} \mathbf{A}^{+}$

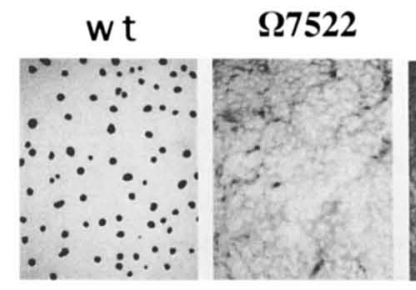

$\mathbf{\Omega 7 5 4 6}$

$\mathbf{\Omega 7 6 3 2}$

$\mathbf{\Omega 7 6 6 3}$
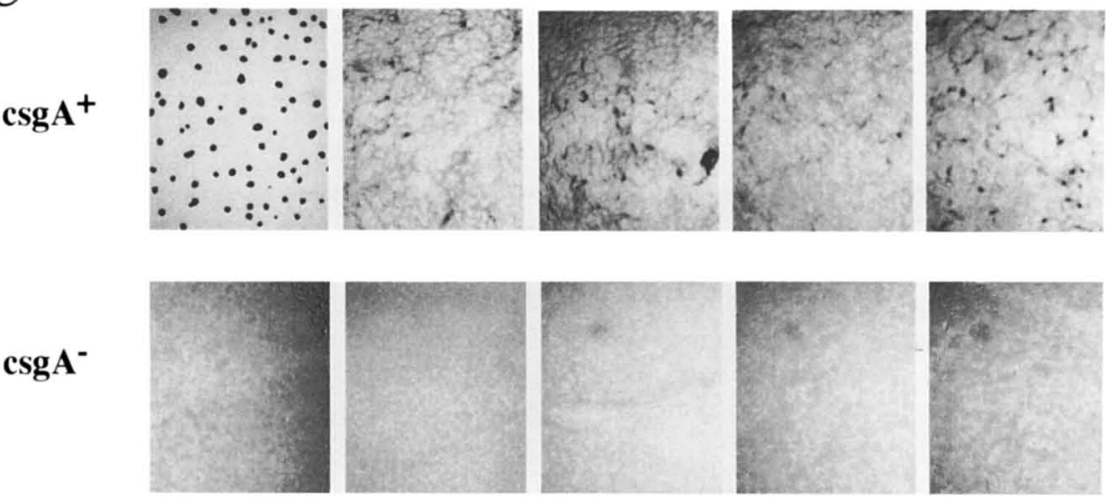

motile (Kim and Kaiser 1990b). To determine rigorously whether any of the Tn5 lac insertions disrupted a gene involved in A or S motility, each Tn5 lac insertion was crossed by $\mathrm{Mx} 4$ transduction into a representative $\mathrm{S}^{-}$ (DK1300 sglG) or A- (DK1219 cglC1) host, and the effect on swarming motility assessed on 1/2CTT agar (see Materials and methods). Strains that carry both an $\mathrm{A}^{-}$and an $\mathrm{S}^{-}$mutation are nonswarming (Hodgkin and Kaiser 1979a,b) and grow as small, smooth-edged colonies. As judged by the structure of the swarming zone around vegetative colonies, none of the $\mathrm{Agg}^{-}$Tn5 lac insertions generated a nonswarming $\left(\mathrm{A}^{-} \mathrm{S}^{-}\right)$phenotype when crossed into either an $\mathrm{A}^{-}$or $\mathrm{S}^{-}$host (data not shown).
Thus, in a manner analogous to a $\operatorname{csg} A$ mutation, none of the mutations resulted in a defect in either of the A or S motility systems.

A screen for $\mathrm{Agg}^{-}$mutants would be expected to identify additional $\operatorname{csg} A$ alleles. To test whether any of the $\mathrm{Agg}^{-}$Tn5 lac insertions mapped to $\operatorname{csg} A$, the $\operatorname{Tn} 5$ lac insertions (which confer $\operatorname{Kan}^{\mathrm{r}}$ ) were crossed into the strain DK5208 that carries the $\operatorname{csg} A:: \operatorname{Tn} 5-132 \Omega L S 205$ allele (which confers $\mathrm{Tet}^{\mathrm{r}}$ ) by $\mathrm{Mx} 4$ transduction. Subsequently, the transductants were scored for the loss of $\mathrm{Tet}^{\mathrm{r}}$. In all cases, $100 \%$ of the resulting $\mathrm{Kan}^{\mathrm{r}}$ transductants were still $\operatorname{Tet}^{\mathbf{r}}$ (data not shown), indicating that the insertions do not map in or close to the $\operatorname{csg} A$ gene. We 
Table 1. Sporulation frequencies of $\mathrm{Agg}^{-} \mathrm{Tn} 5$ lac insertion mutants

\begin{tabular}{|c|c|c|c|c|}
\hline $\mathrm{Agg}^{-}$class & $\begin{array}{l}\text { Tn5 lac } \\
\text { insertion }\end{array}$ & Strain & $\begin{array}{l}\text { Percent } \\
\text { sporulation }\end{array}$ & $\begin{array}{l}\text { Percent sporulation } \\
+ \text { DK1622(wt) }\end{array}$ \\
\hline & & $\begin{array}{l}\text { DK1622 (wt) } \\
\text { DK5208 }(\operatorname{csg} A)\end{array}$ & $\begin{aligned} & 3.2 \\
< & 0.000006\end{aligned}$ & $\begin{array}{l}\text { N.D. } \\
0.8\end{array}$ \\
\hline I & $\begin{array}{l}\Omega 7522 \\
\Omega 7546 \\
\Omega 7632 \\
\Omega 7663\end{array}$ & $\begin{array}{l}\text { DK11017 } \\
\text { DK11064 } \\
\text { DK11019 } \\
\text { DK11020 }\end{array}$ & $\begin{array}{l}1.2 \\
1.2 \\
1.5 \\
1.9\end{array}$ & $\begin{array}{l}\text { N.D. } \\
\text { N.D. } \\
\text { N.D. } \\
\text { N.D. }\end{array}$ \\
\hline II & $\begin{array}{l}\Omega 4491 \\
\Omega 7540 \\
\Omega 7677\end{array}$ & $\begin{array}{l}\text { DK5285 } \\
\text { DK11063 } \\
\text { DK11021 }\end{array}$ & $\begin{array}{l}<0.000006 \\
<0.000006 \\
<0.000006\end{array}$ & $\begin{array}{l}<0.000006 \\
<0.000006 \\
<0.000006\end{array}$ \\
\hline III & $\Omega 7516$ & DK11016 & $<0.000006$ & $<0.000006$ \\
\hline
\end{tabular}

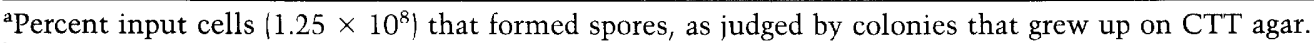

b6.25 $\times 10^{7}$ mutant cells (prepared as described in Materials and methods) were mixed with an equal number of wild-type cells at time zero. Percent values are the number of mutant spores after 3 days of incubation divided by the number of mutant cells at time zero. (N.D.) Not determined.

note that from a total of 10,000 insertions, no insertion in $\operatorname{csg} A$ has been identified, indicating that the Tn5 lac mutagenesis did not saturate the chromosome for " $\operatorname{csg} A$ like" genes.

The Agg ${ }^{-}$mutants were examined for their ability to form spores after $72 \mathrm{hr}$ of starvation in submerged culture (Kuner and Kaiser 1982; Kim and Kaiser 1990b; see Materials and methods) (Table 1). Approximately 3\% of wild-type cells formed spores in this assay in agreement with previous observations (Kim and Kaiser 1990b). The four insertion mutants $\Omega 7522, \Omega 7546, \Omega 7632$, and $\Omega 7663$ (the Tn5 lac insertions are named by a four-digit number that refers to the site of transposon insertion) formed filamentous structures, much smaller and less condensed than wild-type fruiting bodies (Fig. 1A, showing aggregation on agar). Nevertheless, these mutants sporulated at the same level as the wild-type strain (Table 1), although, notably, the spores formed by these four mutants were not contained in the multicellular structures (data presented below). The mutants containing the insertions $\Omega 4491, \Omega 7540, \Omega 7677$, and $\Omega 7516$ sporulated at a very low level, the same as a $\operatorname{csg} A$ mutant (Table 1).

To investigate whether the sporulation defect in the mutants containing $\Omega 4491, \Omega 7540, \Omega 7677$, and $\Omega 7516$ were cell autonomous, wild-type cells were mixed with mutant cells to test if sporulation in the mutants could be rescued by extracellular complementation (Table 1). Sporulation in the four mutants was not rescued by codevelopment with an equal number of wild-type cells. In contrast, sporulation by a $\operatorname{csg} A$ mutant was rescued 100,000 -fold by wild-type cells as observed previously (Kim and Kaiser 1990b). These four mutations being cell autonomous implies that their sporulation defect is not simply caused by the lack of production of an extracellular signal.

C-factor production by the $\mathrm{Agg}^{-}$mutants was measured in vivo by the ability of the mutant strains to rescue development of a $\operatorname{csg} A$ null mutant by extracellular complementation (Table 2). As noted above, codevelopment with a motile $\operatorname{csg} A^{+}$strain, like DK1622, rescues sporulation efficiently in the $\operatorname{csg} A$ strain. The mutants containing insertions $\Omega 7522, \Omega 7546, \Omega 7632$, and $\Omega 7663$ all rescued sporulation of the $\operatorname{csg} A$ tester strain DK5208 efficiently, implying that the developmental block imposed by the Tn5 lac insertions is not in C-factor production or the ability to transmit the C-signal. The mutants with the insertions $\Omega 4491, \Omega 7540$, and $\Omega 7677$ rescued sporulation of the $\operatorname{csg} A$ strain $\sim 10$-fold less efficiently than wild-type cells, whereas the mutant carrying $\Omega 7516$ was unable to rescue sporulation of the $\operatorname{csg} A$ strain. As these four strains are fully motile, the results indicate that $\mathrm{C}$-factor production is partially deficient in the strains carrying the insertions $\Omega 4491$,

Table 2. Sporulation of csgA mutant (DK5208) when codeveloped with $\mathrm{Agg}^{-}$mutants

\begin{tabular}{llll}
\hline & $\begin{array}{l}\text { Tn5 lac } \\
\text { insertion in } \\
\text { Agg }^{-} \text {class }\end{array}$ & $\begin{array}{l}\text { Agg } \\
\text { mutant } \\
\text { codeveloped } \\
\text { with DK5208 }\end{array}$ & $\begin{array}{l}\text { Percent } \\
\text { sporulation } \\
\text { of DK5208 }\end{array}$ \\
\hline & & none & $<0.000006$ \\
& & DK1622 (wt) & 0.8 \\
I & $\Omega 7522$ & DK11017 & 0.8 \\
& $\Omega 7546$ & DK11064 & 1.1 \\
& $\Omega 7632$ & DK11019 & 0.5 \\
II & $\Omega 7663$ & DK1 1020 & 0.6 \\
& $\Omega 4491$ & DK5285 & 0.08 \\
III & $\Omega 7540$ & DK11063 & 0.06 \\
& $\Omega 7677$ & DK11021 & 0.08 \\
& $\Omega 7516$ & DK11016 & $<0.000006$
\end{tabular}

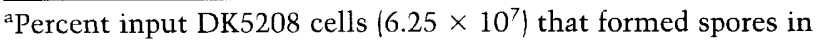
the presence of an equal number of the indicated potential donor cells, as judged by colonies that grew up on agar containing Tet. 
$\Omega 7540$, and $\Omega 7677$ and completely deficient in the strain carrying $\Omega 7516$.

The aggregation phenotypes of the Tn5 lac insertion mutants differed from that of a csgA strain on TPM agar after $24 \mathrm{hr}$ of starvation (Fig. 1A,C). Viewed at a low magnification as in Figure 1C, the mat of $\operatorname{csg} A$ mutant cells was featureless apart from a slight mottling. At the higher magnification of Figure $1 \mathrm{~A}$, the $\operatorname{csg} A$ mutant was observed to form small, rather loose aggregates. The mutants that carried insertions $\Omega 7522, \Omega 7546, \Omega 7632$, and $\Omega 7663$ formed small, dense, irregularly shaped aggregates (Fig. 1A) that tended to be organized in tangled filaments (Fig. 1C). Mutants with insertions $\Omega 449$ l, $\Omega 7540$, and $\Omega 7677$ also resembled each other; they formed large, branched aggregates (Fig. 1A). The mutant with insertion $\Omega 7516$ formed small irregular aggregates.

From these aggregation and sporulation tests the mutants can be divided into three distinct phenotypic classes. Class I consists of the strains carrying the insertions $\Omega 7522, \Omega 7546, \Omega 7632$, and $\Omega 7663$. These mutants are unable to ripple, form small, dense, irregular aggregates that tend to be organized in tangled filaments, sporulate at wild-type levels, and produce wild-type levels of C-factor. Class II consists of the strains carrying insertions $\Omega 4491, \Omega 7540$, and $\Omega 7677$. These mutants are unable to ripple and they form extended, branched linear aggregates. They are unable to sporulate, and are cell autonomous with respect to sporulation (Table 1). They produce reduced amounts of C-factor (Table 2). Finally, the mutant carrying the insertion $\Omega 7516$ is the only member of class III. This mutant is unable to ripple, forms small, nonuniform aggregates, is unable to sporulate, is cell autonomous with respect to sporulation, and does not appear to produce C-factor.

\section{Class I and class II insertions identify genes for components of the C-signal transduction pathway}

Epistasis experiments can provide information about interactions between different genes, including the relative position of gene products in a regulatory pathway (Avery and Wasserman, 1992). To determine whether any of the Tn5 lac insertions affect genes in the C-factor signaling pathway, each of the Tn5 lac insertions was transduced into a $\operatorname{csg} A$ null mutant strain. Subsequently, the developmental phenotypes of the double mutants were examined and compared to those of the strains carrying single mutations.

Double mutant strains carrying a csgA null mutation in combination with any of the class I Tn5 lac insertions ( $\Omega 7522, \Omega 7546, \Omega 7632$, or $\Omega 7663$ ), displayed the aggregation phenotype characteristic of the csgA mutant on TPM agar (Fig. 1B,C). In addition, the levels of sporulation in the double mutant strains in submerged culture were identical to that observed for the $\operatorname{csg} A$ mutant ( $\mathrm{Ta}$ ble 3). These results show epistasis of $\operatorname{csg} A$ over class I for aggregation and sporulation. They provide evidence that the genes identified by the class I insertions are in the same genetic pathway as $\operatorname{csg} A$, and suggest that $\operatorname{csg} A$ acts upstream of the genes identified by the insertions.
Table 3. Effect of a csgA null mutation on the sporulation of $\mathrm{Agg}^{-}$mutants

\begin{tabular}{|c|c|c|c|}
\hline $\begin{array}{l}\mathrm{Agg}^{-} \\
\text {class }\end{array}$ & $\begin{array}{l}\mathrm{Agg}^{-} \text {insertion } \\
\text { combined with } \\
\operatorname{csg} A:: \operatorname{Tn} 5-132 \\
\Omega \mathrm{LS} 205\end{array}$ & Strain & $\begin{array}{l}\text { Percent } \\
\text { sporulation }^{a}\end{array}$ \\
\hline & none & DK5208 & $<0.000006$ \\
\hline I & $\begin{array}{l}\Omega 7522 \\
\Omega 7546 \\
\Omega 7632 \\
\Omega 7663\end{array}$ & $\begin{array}{l}\text { DK11050 } \\
\text { DK11051 } \\
\text { DK11053 } \\
\text { DK11054 }\end{array}$ & $\begin{array}{l}<0.000006 \\
<0.000006 \\
<0.000006 \\
<0.000006\end{array}$ \\
\hline II & $\begin{array}{l}\Omega 4491 \\
\Omega 7540 \\
\Omega 7677\end{array}$ & $\begin{array}{l}\text { DK5296 } \\
\text { DK11074 } \\
\text { DK11055 }\end{array}$ & $\begin{array}{l}<0.000006 \\
<0.000006 \\
<0.000006\end{array}$ \\
\hline III & $\Omega 7516$ & DK11049 & 0.00006 \\
\hline
\end{tabular}

apercent input cells $\left(1.25 \times 10^{8}\right)$ that formed spores, as judged by colonies that grew up on CTT agar.

Double mutant strains carrying a $\operatorname{csg} A$ null mutation in combination with any of the class II Tn5 lac insertions ( $\Omega 4491, \Omega 7540$, or $\Omega 7677$ ) displayed the aggregation phenotype characteristic of the Tn5 lac insertion mutants forming branched linear aggregates (Fig. 1B) as observed previously for the $\Omega 4491$ insertion (Kroos and Kaiser 1987; Kroos et al. 1990). The sporulation levels of the double mutant strains under submerged culture conditions were at the same low levels as observed for both the $\operatorname{csg} A$ null strain and the Tn5 lac insertion strains (Table 3). The low level of sporulation in these strains precludes a test of epistasis based on spore levels. However, the aggregation data indicate that class II insertion mutations are epistatic to the $\operatorname{csg} A$ mutation with respect to aggregation. This epistasis is interpreted in the Discussion.

A strain containing both a $\operatorname{csg} A$ mutation and the class III insertion $\Omega 7516$ displayed an aggregation phenotype that differed from strains that carried either mutation singly (Fig. 1B). Moreover, the double mutant strain sporulated $\geqslant 10$-fold more than the strains that carry the constituent single mutations (Table 3; cf. Table 1). In this case no clear epistasis relationship can be deduced and it is not possible to conclude whether the gene identified by the insertion acts in the same regulatory pathway as $\operatorname{csg} A$. Therefore, this mutation will not be considered further in this work.

\section{The class I Tn5 lac insertions map to the frz locus}

The class I mutants share characteristics with frz mutants; both are unable to ripple (Sager and Kaiser 1994), both aggregate improperly (Zusman 1982), whereas their ability to sporulate is not adversely affected (Zusman 1982). The frz genes code for a set of proteins that make up a signal transduction system that controls the frequency of single cell reversals (Blackhart and Zusman 1985b; McCleary et al. 1990; McBride et al. 1992). To test whether the $\mathrm{Tn} 5 \mathrm{lac}$ insertions in the $\mathrm{Agg}^{-}$strains 
might be linked to, or inserted in the frz locus, two approaches were used. First, the linkage of the Tn5 lac insertions to the marker frzE:: $\operatorname{Tn} 5\left(\operatorname{Tet}^{\mathrm{r}}\right) \Omega 231$ (Fig. 2A), in the strain DZF4041, was tested by transduction. Mx8 phage were grown on the strains containing the Tn5 lac insertions and transduced into DZF4041. In each of the class I insertions, close to $100 \%$ of the transductants had lost the frzE::Tn5(Tet $\left.{ }^{\mathrm{r}}\right) \Omega 231$ marker, indicating that the class I insertions were linked closely to or within the frz locus. None of the class II insertions were linked to the frzE marker. In a second approach, the insertion points of the class I insertions were mapped physically using probes that either hybridized to the $5^{\prime}$ end of the $1 a c Z$ gene in Tn5 lac or to the frz locus. $\Omega 7522$ and $\Omega 7546$ had identical physical maps upstream of their Tn 5 lac insertion points with both probes (Fig. 2A). The frz probe allowed for a detailed mapping of the insertion points, and demonstrated that the physical maps of $\Omega 7522$ and $\Omega 7546$ were consistent with insertions in frzF (Fig. 2A). Similar analyses demonstrated that the physical maps of $\Omega 7632$ and $\Omega 7663$ were compatible with insertions in frzE and frzCD, respectively (Fig. 2A).

The three class II Tn5 lac insertions are closely linked Southern blot analyses with the lacZ-specific probe sug- gested that insertions $\Omega 7540$ and $\Omega 7677$ were inserted in the same orientation and separated by $0.3 \mathrm{~kb}$, as the physical maps of the DNA upstream of the insertions could be brought into register as shown (Fig. 2B). However, the physical map of the DNA upstream of insertion $\Omega 4491$ was different from that of $\Omega 7540$ and $\Omega 7677$ (data not shown; Fig. 2B). To analyze the physical relationship between these insertions, we again used two approaches. First, the linkage of $\Omega 7540$ and $\Omega 7677$ to $\Omega 4491$ was tested by transduction experiments using as a recipient the strain DK11075. This strain contains a derivative of $\Omega 4491$ in which the $\mathrm{Kan}^{\mathrm{r}}$ gene has been replaced by a Tet $^{\mathrm{r}}$ element (see Materials and methods). Thus, the $\Omega 7540$ and $\Omega 7677$ insertions were transduced into DK11075. All of the resulting $\mathrm{Kan}^{\mathbf{r}}$ transductants were found to be Tet $^{\mathrm{s}}$, indicating that the $\Omega 4491, \Omega 7540$, and $\Omega 7677$ insertions are linked closely. Subsequently, Southern blot analyses with a probe specific for the region immediately upstream of $\Omega 7540$ cloned in plasmid pFS703 (see Materials and methods) showed that insertion $\Omega 4491$ changed the restriction fragment lengths in the neighborhood of $\Omega 7540$, and mapped $\Omega 44910.7 \mathrm{~kb}$ downstream of $\Omega 7540$ in an orientation opposite to that of $\Omega 7540$ and $\Omega 7677$, as shown in Figure $2 B$. $\Omega 4491$ has been mapped previously to the Ase I fragment P on the physical map of the $M$. xanthus chromosome /Chen et al. 1991; He et al. 1994).

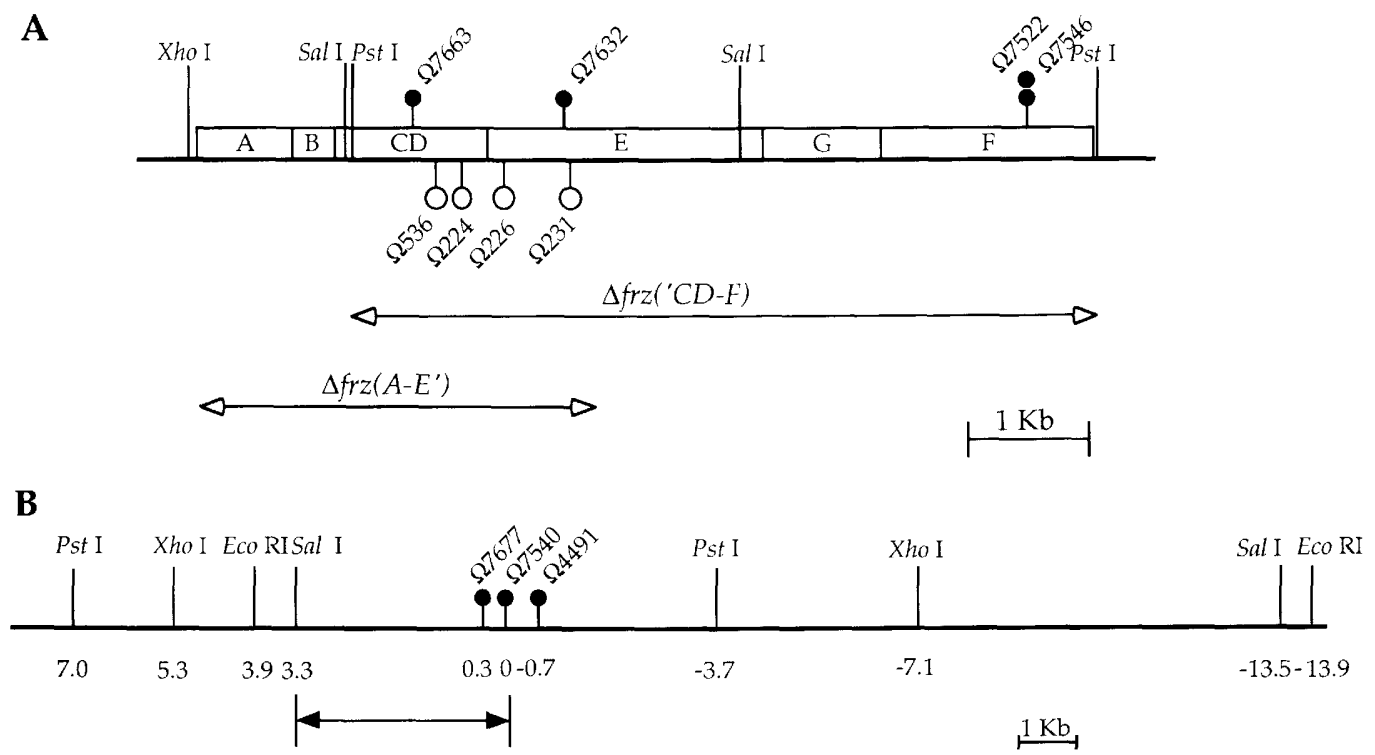

Figure 2. (A) Map of the frz locus and position of insertion mutations. The top line shows the frz locus with restriction sites used in the Southern blot analyses of the class I insertions; structural genes are indicated by open boxes. The insertion sites of the four class I mutation are marked by the labeled, filled-in lollipops. Open lollipops mark the insertion sites of the Tn5 elements that were used in the linkage and reconstruction experiments (cf. Table 7 for reference). In the second and third lines the regions deleted in the $\Delta f r z(' \mathrm{CD}-\mathrm{F})$ and $\Delta f r z\left(\mathrm{~A}-\mathrm{E}^{\prime}\right)$ alleles are shown. (B) Physical map of the region containing the three class II insertions. Restriction sites used to map the insertions, indicated by filled-in lollipops, are shown. $\Omega 4491$ is inserted in an orientation opposite to that of $\Omega 7540$ and $\Omega 7677$. Distances are measured in kbp from the insertion site of Tn 5 lac $\Omega 7540$; sites to the left and right of $\Omega 7540$ have a positive and negative value, respectively. The physical map of $\Omega 4491$ has been published previously (Kroos et al. 1986). The revised map differs slightly from that previously published, but the overall pattern remains unchanged. The double-ended arrow indicates the DNA fragment that was used as a probe to map the relative insertion points of the three class II insertions. 


\section{A model for the C-factor signaling pathway}

The sporulation and aggregation data suggest that the genes identified by the class I and II insertions act in the $\operatorname{csg} A$ pathway. On the one hand, the class I mutations resulted in a defect in the rippling and aggregation part of the C-factor response, leaving sporulation and C-factor production intact. On the other hand, the class II mutants had defects in all four C-factor responses including $\mathrm{C}$-factor production. The class II mutants are cell autonomous, thus suggesting that the primary defect in the class II mutants is on the reception side of the C-factor signal rather than in the production of $\mathrm{C}$-factor. The data also suggest that the class I insertions identify genes that code for components that are only involved in the motility responses to $\mathrm{C}$-factor, whereas the class II insertions identify genes that code for components that are involved in all the C-factor responses. All these observations can be explained by a model for the $\mathrm{C}$-signaling pathway in which the first part is common to all C-factor-dependent responses and is the target of the class II insertions. Downstream of class II the pathway branches; one branch leads to the motility responses and includes the Frz proteins, and the second branch leads to the sporulation and C-factor production response (Fig. 6, below).

\section{Testing for a branch in the C-factor signaling pathway}

Several specific predictions from the model presented above could be tested in reconstruction experiments with several characterized frz loss-of-function alleles and a frz gain-of-function allele in combination with either a $\operatorname{csg} A$ null allele or a class II insertion. First, the epistasis relationship between frz loss-of-function alleles and $\operatorname{csg} A$ was tested; the prediction is that a $\operatorname{csg} A$ null mutation should be epistatic to the frz loss-of-function alleles (Avery and Wasserman 1992). The frz loss-of-function alleles were transduced into the fully motile wildtype strain DK1622 and the isogenic strain DK5208, which contains the $\operatorname{csg} A$ null allele. The $f_{r z}$ loss-of-function alleles, which included two insertion mutations (frzCD::Tn5 lac $\Omega 536$ and frzE::Tn5 $\Omega 226$ ) and two deletions $\left(\left.\Delta f r z\right|^{\prime} C D-F\right)$ and $\Delta f r z\left(A-E^{\prime}\right)$ (Fig. 2A), have on their own an aggregation defect similar to that caused by the class I insertions, as expected (Fig. 3). They conferred an inability to ripple (data not shown) as previously observed with the frzCD::Tn5 lac $\Omega 536$ allele (Sager and Kaiser 1994), and they did not result in a sporulation defect (Table 4). Also, with these frz mutants it was observed that the spores formed were not contained in aggregates (Fig. 4). Moreover, the frz mutants rescued sporulation of a $\operatorname{csg} A$ null mutant in codevelopment assays as efficiently as the wild-type strain (Table 5). The $\operatorname{csg} A$ mutation proved to be epistatic to the frz loss-offunction alleles, when the $\operatorname{csg} A$, frz double mutants were tested for their ability to sporulate (Table 4) and aggregate (see Fig. 3). Because the functional and genetic characteristics of the single and double mutant strains containing $f_{r z}$ loss-of-function alleles are identical to those observed with the class I mutants, this reasserts the mapping of the class I insertions to the frz locus.

The availability of the $f r z$ allele frzCD::Tn5 $\Omega 224$ (from here on denoted frzD; Blackhart and Zusman 1985a/ provided a critical tool for testing the model for a branched C-signaling pathway. The frzD allele contains Tn5 inserted near the carboxyl end of frzCD (McBride et al. 1989; see Fig. 2A). Based on two criteria frzD behaves as a gain-of-function allele: (1) Its phenotype is distinct from and opposite to that caused by the frz loss-of-function mutations with respect to single cell reversal frequency [increased frequency for gain-of-function versus decreased frequency for loss-of-function alleles (McCleary et al. 1990; Blackhart and Zusman 1985b)]. (2) The frzD allele is dominant to the wild-type allele in a merodiploid strain (Blackhart and Zusman 1985a,b; McBride et al. 1989). If $f r z$ is involved only in the motilityrelated branch of the $\mathrm{C}$-factor pathway as depicted in Figure 6, then a frz gain-of-function allele would be predicted to be epistatic to a $\operatorname{csg} A$ null mutation with respect to the aggregation phenotype and but not with respect to the sporulation phenotype. To test this prediction, DK1622 and DK5208 derivatives that contain the frzD allele were constructed. The DK1622 derivative that carried the frzD allele had the characteristic non-

Figure 3. Aggregation patterns of $f_{r z}$ and $\operatorname{csg} A^{-}, f r z$ double mutants. For each strain, $20 \mu \mathrm{l}$ of a cell suspension with a calculated cell density of 500 Klett units/ $\mathrm{ml}$ in TPM buffer was placed on a TPM agar plate, and the cells allowed to develop for $24 \mathrm{hr}$. The relevant $f_{r z}$ allele is abbreviated above each column; the full names of the alleles used are from left to right frzCD::Tn5 lac $\Omega 536$, frzE::Tn5 $\Omega 226$, $\Delta f r z\left(A-E^{\prime}\right):: \operatorname{Kan}^{\mathrm{r}}, \quad \Delta f_{r z}\left({ }^{\prime} C D-F\right):: \mathrm{Kan}^{\mathrm{r}}$, and frzCD::Tn5 lac $\Omega 224$. The top row shows the aggregation phenotype caused by the respective $f_{r z}$ mutation in a $\operatorname{csg} A^{+}$background; the bottom row shows the aggregation phenotype in a $\operatorname{csg} A^{-}$background. The strains used are (from top, left to bottom, right): DK1622, DK8505,DK9711, DK9032, DK9033, DK8506, DK5208, DK9037, DK9048, DK9034, DK9035, DK9036. Bar, 1 mm.

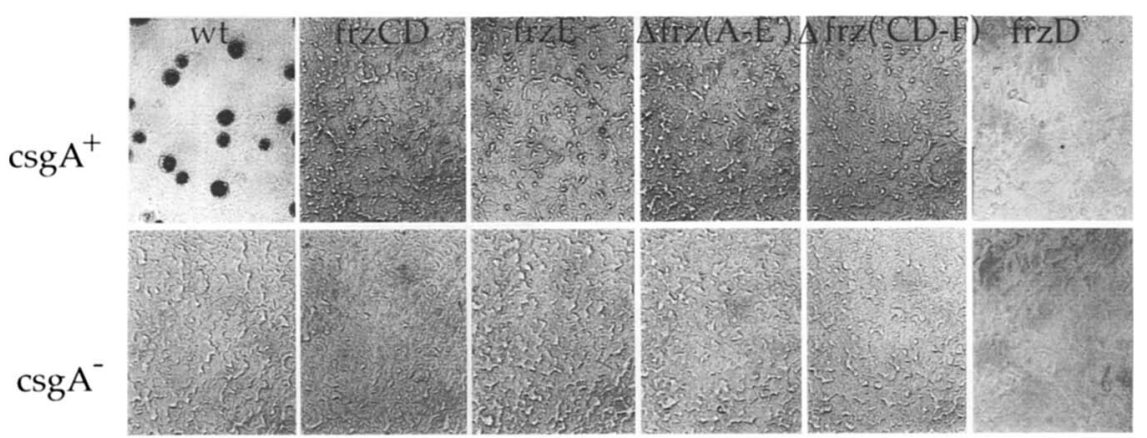


Table 4. Sporulation of frz mutants in $\operatorname{csg} \mathrm{A}^{\prime}$ and csgA- backgrounds

\begin{tabular}{lcl}
\hline & $\begin{array}{l}\text { Percent } \\
\text { sporulation } \\
\text { in } c s g A^{\mathrm{b}} \\
\text { background }\end{array}$ & $\begin{array}{l}\text { Percent } \\
\text { sporulation }^{\mathrm{b}} \\
\text { in } c s g A^{-} \\
\text {background }^{\mathrm{c}}\end{array}$ \\
\hline Willele type & 1.3 & $<0.000006$ \\
frzCD::Tn5 lac $\Omega 536$ & 0.6 & $<0.000006$ \\
frzE::Tn5 $\Omega 226$ & 1.3 & $<0.000006$ \\
$\Delta f r z\left(A-E^{\prime}\right):: \mathrm{Kan}^{\mathrm{r}}$ & 1.0 & $<0.000006$ \\
$\Delta f r z\left({ }^{\prime} C D-F\right):: \mathrm{Kan}^{\mathrm{r}}$ & 1.9 & $<0.000006$ \\
frzCD::Tn5 $\Omega 224$ & 3.2 & $<0.000006$
\end{tabular}

${ }^{a}$ All frz mutations used are loss-of-function alleles except for frzCD::Tn5 $\Omega 224$, which is a gain-of-function allele. This allele is denoted frzD in the text and in Figs. 3 and 4.

${ }^{b}$ Percent of input cells $\left(1.25 \times 10^{8}\right)$ that formed spores, as judged by colonies that grew up on CTT agar.

${ }^{c} \operatorname{csg} A$ allele is $\operatorname{csg} A:: \operatorname{Tn} 5-132 \Omega L S 205$.

spreading, relatively smooth cell mat of $f r z D$ strains (see Fig. 3; Blackhart and Zusman 1985a); it was unable to form aggregates on either TPM agar plates (see Fig. 3) or in submerged culture (Fig. 4). It did not form ripples (Sager and Kaiser 1994; data not shown). It sporulated at wild-type levels (Table 4), and produced wild-type levels of $\mathrm{C}$-factor based on its ability to rescue development of a $\operatorname{csg} A$ mutant (Table 5). Most important, the $\operatorname{csg} A$, frzD double mutant had the aggregation phenotype characteristic of the frzD single mutation strain (see Fig. 3), whereas it had the sporulation phenotype characteristic of the $\operatorname{csg} A$ single mutation strain (Table 4). Therefore, these data support a branched C-signal transduction pathway in which the Frz proteins are involved in the motility response to $\mathrm{C}$-signaling and not in the sporulation response.

The model for the branched C-signaling pathway also

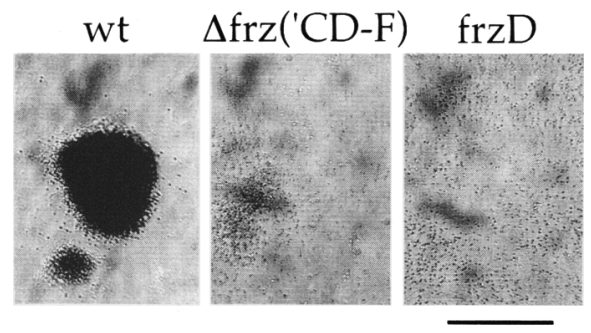

Figure 4. Aggregation and spore formation in frz mutants in submerged culture. For each strain, $400 \mu \mathrm{l}$ of a cell suspension with a calculated density of 62.5 Klett was placed in a $15-\mathrm{mm}$ microtiter well and then incubated for $72 \mathrm{hr}$. The frz allele present in a strain is abbreviated above each panel; the full names of the alleles used are $\left.\Delta f r z\right|^{\prime} C D-F \mid:: \operatorname{Kan}^{\mathrm{r}}$ and $f r z C D:: \operatorname{Tn} 5$ $\Omega 224$. After $72 \mathrm{hr}$ of starvation, the wild-type strain (DK1622) has formed dark spore-filled fruiting bodies, relatively few spores (the small dark dots) are visible outside of the fruiting bodies. The two frz strains fail to aggregate and the spores are visible as tiny, refractile black dots. The strains used are (from left to right): DK1622, DK9033, DK8506. Bar, $100 \mu \mathrm{m}$.
Table 5. Sporulation of a csgA mutant (DK5208) when codeveloped with frz mutants

\begin{tabular}{llc}
\hline frz allele & $\begin{array}{l}\text { Strain } \\
\text { codeveloped } \\
\text { with DK5208 }\end{array}$ & $\begin{array}{l}\text { Percent sporulation } \\
\text { of DK5208 }\end{array}$ \\
\hline Wild type & none & $<0.000006$ \\
frzCD::Tn5 lac $\Omega 536$ & DK1622 & 1.0 \\
frzE::Tn5 $\Omega 226$ & DK8505 & 0.3 \\
$\Delta f r z\left(A-E^{\prime}\right):: \operatorname{Kan}^{\mathrm{r}}$ & DK9711 & 0.8 \\
$\Delta f r z\left({ }^{\mathrm{r}} C D-F\right):: \mathrm{Kan}^{\mathrm{r}}$ & DK9032 & 0.7 \\
frzCD::Tn5 $\Omega 224$ & DK9033 & 0.6 \\
& DK8506 & 1.0
\end{tabular}

${ }^{a}$ All frz mutations used are loss-of-function alleles except for frzCD::Tn5 $\Omega 224$, which is a gain-of-function allele. This allele is denoted frzD in the text and in Figs. 3 and 4.

${ }^{b} 6.25 \times 10^{7} \operatorname{csg} A$ mutant cells (prepared as described in Materials and methods) were mixed with an equal number of potential donor cells. Percent values are the number of $\operatorname{csg} A$ mutant spores after 3 days of incubation divided by the number of $\operatorname{csg} A$ mutant cells at time zero, as judged by colonies that grew up on agar containing Tet.

predicts that a class II mutation should be epistatic to $f_{r z}$ loss-of-function mutations with respect to both aggregation and sporulation, but epistatic to a frz gain-of-function mutation only with respect to sporulation. To test these predictions, double mutants containing the class II insertion $\Omega 7540$, and the frz loss-of-function allele frzE::Tn5(Tet $\left.{ }^{\mathrm{r}}\right) \Omega 231$, or the frz gain-of-function allele frzCD::Tn5(Tet ${ }^{\mathrm{r}}$ ) $\Omega 224$ (see Fig. 2A) were constructed. The double mutant strain carrying both $\Omega 7540$ and the frzE loss-of-function allele had the aggregation (Fig. 5) and the sporulation phenotypes (Table 6) characteristic of the $\Omega 7540$ mutation. However, the strain carrying $\Omega 7540$ and the frzD gain-of-function allele had the aggregation phenotype characteristic of the frz $D$ allele (Fig. 5) and the sporulation phenotype characteristic of the $\Omega 7540$ insertion (Table 6). These results support the location of the class II genes upstream of the frz genes and the position of a bifurcation downstream of the class II genes.

\section{Expression of C-factor-dependent genes in frz mutants}

Mutations in $\operatorname{csg} A$ decrease the level of expression of certain developmentally regulated genes, known for that reason as C-factor-dependent genes (Kroos and Kaiser 1987). As monitored by transcriptional fusions to lacZ, such genes are expressed at $6 \mathrm{hr}$ or later into development of wild type, whereas in $\operatorname{csg} A$ mutants their expression is either decreased or abolished. If the C-factor signal transduction pathway is branched at the position shown in Figure 6, and if as indicated in that model frz function is required for the motility responses but not for gene expression, then frz mutants should retain normal levels of C-factor-dependent gene products.

To test this prediction, the frz loss-of-function allele 


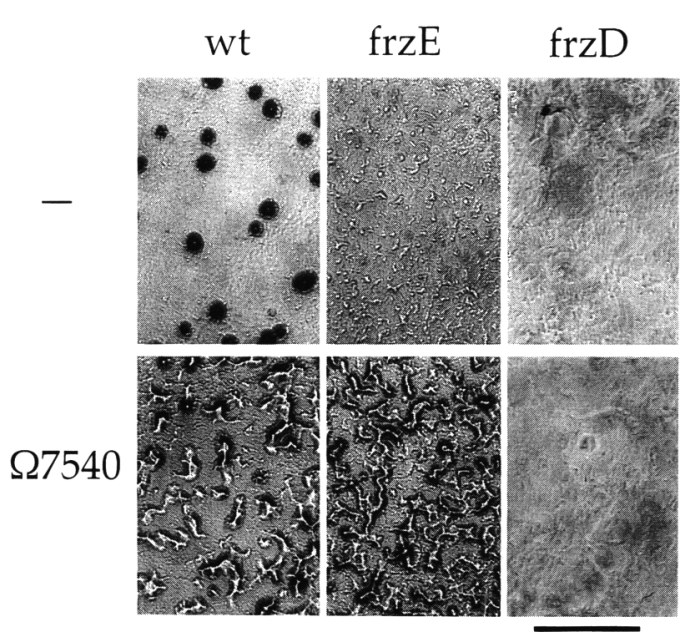

Figure 5. Aggregation of $f_{r z} E$ or $f_{r z} D$ mutants with or without Tn5 lac $\Omega 7540$. $20 \mu$ l of a cell suspension with a calculated density of 1000 Klett units in TPM buffer was placed on a TPM agar plate, and the cells allowed to develop for $24 \mathrm{hr}$. The frz alleles used are abbreviated above each column; the full names of the alleles used are frzE::Tn5(Tet $\left.{ }^{r}\right) \Omega 231$, and $f_{r z} C D:: \operatorname{Tn} 5\left(\operatorname{Tet}^{\mathrm{r}}\right)$ $\mathbf{\Omega 2 2 4}$. The top row shows the aggregation phenotype in a strain that contains Tn5 lac $\Omega 4499$ (Kroos et al. 1986); the bottom row shows the aggregation phenotype associated with the same frz alleles in a strain that also contains Tn5 lac $\Omega 7540$. Tn5 lac $\Omega 4499$ has no known effect on sporulation or aggregation (Kroos et al. 1986) but is present in the strains to control for the presence of a Tn5 lac element. The strains used are (from top left to bottom right): DK4499, DK9038, DK9043, DK11063, DK9049, and DK9050. Bar, $1 \mathrm{~mm}$.

frzE::Tn5(Tet $\left.{ }^{\mathrm{r}}\right) \Omega 231$ and the frz gain-of-function allele frzCD::Tn5(Tet $\left.{ }^{\mathrm{T}}\right) \Omega 224$ were transduced into strains containing $\mathrm{C}$-factor-dependent fusions, and $\beta$-galactosidase expressed from the fusions was measured. Five C-factordependent transcriptional fusion reporters $(\Omega 4401, \Omega 4403$, $\Omega 4414, \Omega 4435$, and $\Omega 4499$ ) were analyzed, which have

Table 6. Effect of Tn5 lac $\Omega 7540$ on the sporulation of frz mutants

\begin{tabular}{lll}
\hline & $\begin{array}{l}\text { Percent } \\
\text { sporulation } \\
\text { in strain } \\
\text { not carrying } \\
\text { Tn5 lac } \Omega 7540^{\mathrm{b}, \mathrm{c}}\end{array}$ & $\begin{array}{l}\text { Percent } \\
\text { sporulation } \\
\text { in strain } \\
\text { carrying Tn5 lac } \\
\Omega 7540^{\mathrm{c}}\end{array}$ \\
frz allele $^{\mathrm{a}}$ & 3.8 & $<0.000006$ \\
\hline Wild type & 2.2 & $<0.000006$ \\
frzE::Tn5(Tet $\left.{ }^{\mathrm{r}}\right) \Omega 231$ & 4.0 & $<0.000006$ \\
frzCD::Tn5(Tet $\left.{ }^{\mathrm{r}}\right) \Omega 224$ & & $<$ \\
\hline
\end{tabular}

${ }^{a}$ frzE::Tn5(Tet $\left.{ }^{r}\right) \Omega 231$ and $f_{r z} C D: \operatorname{Tn} 5\left(\operatorname{Tet}^{\mathrm{r}}\right) \Omega 224$ are loss-of-function and gain-of-function alleles, respectively; frzCD::Tn5(Tet ${ }^{\mathrm{r}}$ ) $\Omega 224$ is denoted frzD in the text and in Fig. 5 .

${ }^{\mathrm{b}}$ The strains that do not contain $\Omega 7540$ contain Tn5 lac $\Omega 4499$. Tn5 lac $\Omega 4499$ is a developmentally expressed Tn5 lac insertion with no known effect on aggregation or sporulation (Kroos et al. 1986).

${ }^{\mathrm{c} P e r c e n t}$ input cells $\left(1.25 \times 10^{8}\right)$ that formed spores, as judged by colonies that grew up on CTT agar.

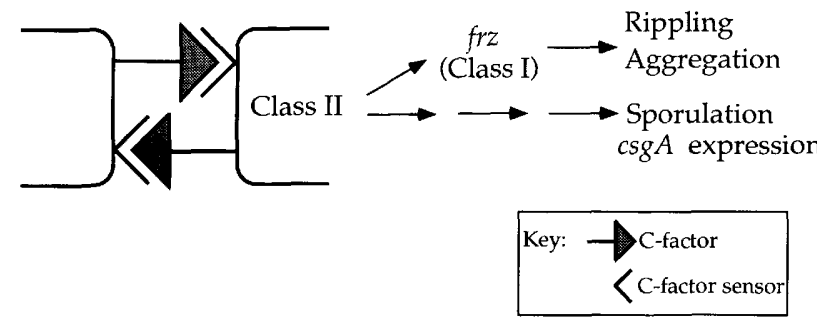

Figure 6. Model for the C-factor signal transduction pathway. The cell-surface associated C-factor on one cell interacts with a sensor on (or in) a second cell, leading to the activation of the intracellular signal transduction pathway. The first part of the pathway is shared by all C-factor-dependent activities and defined by the class II insertions. Farther downstream, the pathway branches: One branch leads to the motility response to $\mathrm{C}$-factor, and the second branch leads to the sporulation and $\operatorname{csg} A$ expression part of the response. The Frz/class I proteins are components in the branch leading to the motility response. For simplicity, the C-factor is shown as the signal interacting directly with the sensor. The molecular nature of the $\mathrm{C}$-factor signal and C-factor sensor is unknown. The reciprocal stimulation of both cells as shown in the diagram is not a prerequisite for activation of the pathway as evidenced by the extracellular complementation of $\operatorname{csg} A$ cells by wild-type cells. The model does not exclude other components and branchpoints in the pathway.

expression times ranging from $6 \mathrm{hr}(\Omega 4499)$ to $25 \mathrm{hr}$ ( $\Omega 4401$ ). The five Tn5 lac fusions provide a test for correct timing of $\mathrm{C}$-factor-dependent gene expression as well as its level. Specific activities of $\beta$-galactosidase expressed by each fusion in both loss-of-function and gainof-function frz mutants are shown in Figure 7. For comparison, $\beta$-galactosidase expression in wild-type and $\operatorname{csg} A$ cells is included. These measurements show similar expression times of the fusions in the frz mutants and in the wild-type strain throughout the 6- to 25 -hr interval; in particular, there was no indication of an expression delay in the frz mutant background. Importantly, the level of $\beta$-galactosidase expression is not decreased by either the frz loss- or gain-of-function alleles; the fusion genes $\Omega 4499, \Omega 4414, \Omega 4403$, and $\Omega 4435$ may even be expressed at a higher level in both types of $f r z \mathrm{mu}-$ tants. These data support a bifurcation in the C-signal transduction pathway, past which one branch includes frz function (and motility responses), whereas the other branch leads to expression of at least five genes and regulation of $\operatorname{csg} A$ expression.

\section{Discussion}

Based on the results presented, a model for the C-signal transduction pathway is proposed (Fig. 6). The signaling event in this pathway is the interaction between C-factor signal from one cell acting on the $\mathrm{C}$-signal sensor belonging to a second cell. (It should be understood that the nature and location of the C-signal sensor on or in the signaled cell are not being specified by the model.) This interaction activates the signaling pathway in the signaled cell. Once received by a cell, the signal is trans- 


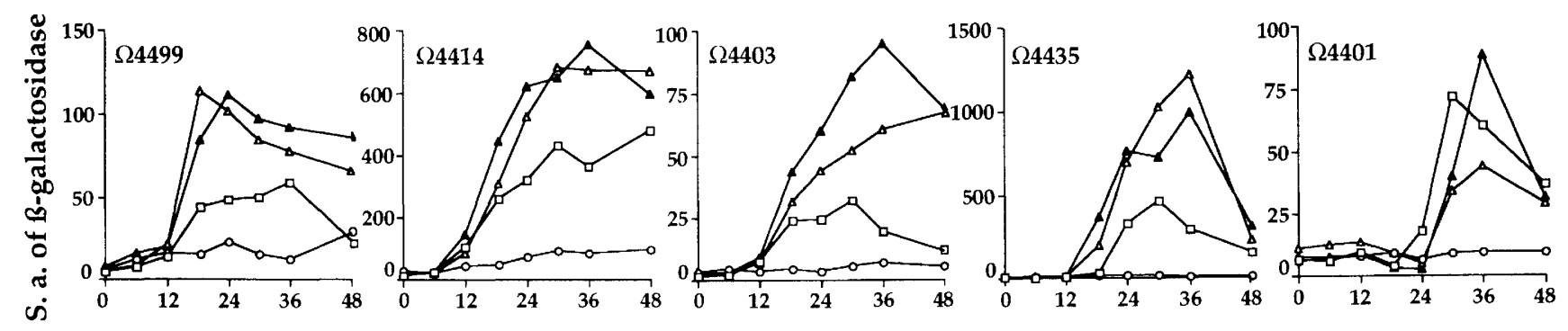

Hours of development

Figure 7. Developmental expression of $\beta$-galactosidase from Tn 5 lac insertions. Specific activity of $\beta$-galactosidase is expressed from five C-factor-dependent Tn5 lac fusions. $\beta$-galactosidase expressed by the Tn5 lac fusions in wild-type cells $(\square)$, csg $A$ cells $(O)$, frzE::Tn5 $\left(\operatorname{Tet}^{\mathrm{r}}\right) \Omega 231$ cells $(\triangle)$, and frzCD::Tn5(Tet $\left.{ }^{\mathrm{r}}\right) \Omega 224$ cells $(\mathbf{\Delta})$ was determined as described in Materials and methods. Specific activity of $\beta$-galactosidase is given as nanomoles of orthonitrophenyl phosphate per minute per milligram of protein. The averages of two determinations from each of two cultures are given. Strains are listed in the order wild-type cells, $\operatorname{csg} A$ cells, frzE cells, and frzCD cells. (Strains containing $\Omega 4499$ ) DK4499, DK5246, DK9038, DK9043; (strains containing $\Omega 4414$ ) DK5279, DK5287, DK9039, DK9044; (strains containing $\Omega 4403$ ) DK4368, DK5270, DK9040, DK9045; (strains containing $\Omega 4435$ ) DK5204, DK5253, DK9042, DK9047; (strains containing $\Omega 4401$ ) DK4293, DK5229, DK9041, DK9046.

duced through the class II gene product that is essential to all the $\mathrm{C}$-factor responses. Downstream of the class II gene product, the pathway contains a branchpoint: one branch leads to the motility responses to $\mathrm{C}$-factor (rippling and aggregation), whereas the second branch leads to sporulation and control of gene expression, including the $\operatorname{csg} A$ gene. In this model, the Frz proteins are components in the motility response branch.

A downstream location of the class II genes relative to the C-factor/sensor interaction in this pathway is implied by the cell autonomy of the class II mutants. Nevertheless, the class II mutations are found to be epistatic to a $\operatorname{csg} A$ null allele with respect to aggregation (Fig. $1 \mathrm{~B}$ ), as if class II preceded C-factor. This paradox can be explained by the C-factor-dependent induction of $\operatorname{csg} A$ expression (Kim and Kaiser 1991). Such induction is observed from the outside in: Addition of purified C-factor to $\operatorname{csg} A$ cells increases $\operatorname{csg} A$ expression as monitored by a csgA-lacZ fusion (Kim and Kaiser 1991). This induction implies a pathway leading from $\mathrm{C}$-factor outside the cell to an increase of $\operatorname{csg} A$ gene expression within that cell. Because the class II mutants produce $\sim 10$-fold less C-factor than wild-type cells (Table 2), the class II gene products are likely components in the pathway that elevates $\operatorname{csg} A$ expression, which would position the class II gene product upstream of $\operatorname{csg} A$ expression in a $\mathrm{C}$-factorproducing cell. This combination of observations, the cell autonomy of class II mutants, the increase in $\operatorname{csg} A$ gene expression when $\mathrm{C}$-factor is added, and the epistasis of class II insertions over csgA suggest that the class II genes act downstream of signal transmission between two cells but upstream of $\operatorname{csg} A$ expression in a cell that is producing $\mathrm{C}$-factor. Ordering of genes based on genetic epistasis experiments in a signaling pathway that increases production of the signal molecule is a special situation, because closing the loop in such a pathway places every gene in that pathway upstream as well as downstream of every other gene in the same pathway. In that sense, all the components (C-factor, sensor, class II gene products, $\operatorname{csg} A$ expression) in the lower branch in
Figure 6 are all upstream as well as downstream of each other.

A branchpoint in the C-signaling pathway is implied by the characteristics of frz mutants - both those isolated by Zusman and co-workers (Table 7) and those newly isolated in this work as class I. Under development-inducing conditions, mutants with frz loss-offunction alleles sporulate and produce C-factor at normal levels, yet they are aggregation deficient. That the sporulation of $f_{r z}$ mutants remains $\mathrm{C}$-factor dependent is shown by the low level of sporulation of $\operatorname{csg} A$, frz double mutants. The model in Figure 6 predicts that developmental expression of C-dependent genes would be normal in frz mutants. In line with this prediction, the level of expression of five different C-factor-dependent genes suffered no decrement as a consequence of either frz lossof-function or $f_{r z}$ gain-of-function mutations. Results of Kashefi and Hartzell (1995) and Weinberg and Zusman (1989) using mutations in different $f_{r z}$ genes, different strain backgrounds and different reporter genes also fit this prediction. Finally, a $f_{r z}$ gain-of-function allele is epistatic to a $\operatorname{csg} A$ mutation or a class II insertion mutation with respect to aggregation but not with respect to sporulation. All these data are consistent with the branchpoint downstream of the class II components shown in Figure 6, which shows how the Frz proteins would be required for the C-factor-dependent motility functions but not for the C-factor-dependent sporulation and gene expression, including the expression level of $\operatorname{csg} A$. Components specific to the lower branch in the pathway of Figure 6 have yet to be identified. The absence of such mutants in the group examined here is consistent with that model and the use of a screen for mutants with an aggregation defect. Mutations in genes specific to the lower branch may have little or no effect on aggregation. Other screening criteria may have to be applied to identify components in this branch.

M. xanthus and Dictyostelium discoideum share several developmental features although they are widely separated evolutionarily (Kaiser 1993). In D. discoideum 
Søgaard-Andersen et al.

Table 7. Myxococcus xanthus strains used

\begin{tabular}{|c|c|c|}
\hline Strain & Relevant genotype & Reference or source \\
\hline DK1219 & $\operatorname{cglC1}$ & Hodgkin and Kaiser (1979b) \\
\hline DK 1300 & $\operatorname{sglG}$ & Hodgkin and Kaiser (1979b) \\
\hline DK1622 & wt & Kaiser (1979) \\
\hline DK4293 & Tn5 lac $\Omega 4401$ & Kroos et al. (1986) \\
\hline DK4368 & Tn5 lac $\Omega 4403$ & Kroos et al. (1986) \\
\hline DK4499 & Tn5 lac $\Omega 4499$ & Kroos et al. (1986) \\
\hline DK5204 & Tn5 lac $\Omega 4435$ & Kroos et al. (1986) \\
\hline DK5208 & $\operatorname{csg} A:: \operatorname{Tn} 5-132 \Omega \mathrm{LS} 205$ & Shimkets and Asher (1988); Kroos and Kaiser (1987) \\
\hline DK5229 & Tn5 lac $\Omega 4401, \operatorname{csg} A:: \operatorname{Tn} 5-132$ RLS205 & Kroos and Kaiser (1987) \\
\hline DK5246 & Tn5 lac $\Omega 4499, \operatorname{csg} A:: \operatorname{Tn} 5-132$ SLS205 & Kroos and Kaiser (1987) \\
\hline DK5253 & Tn5 lac $\Omega 4435, \operatorname{csg} A:: \operatorname{Tn} 5-232 \Omega L S 205$ & Kroos and Kaiser (1987) \\
\hline DK5270 & Tn5 lac $\Omega 4403, \operatorname{csg} A:: \operatorname{Tn} 5.132$ SLS205 & Kroos and Kaiser (1987) \\
\hline DK5279 & $\operatorname{Tn} 5$ lac $\Omega 4414$ & Kroos and Kaiser (1987) \\
\hline DK5285 & Tn5 lac $\Omega 4491$ & Kroos et al. $(1990)$ \\
\hline DK5287 & Tn5 lac $\Omega 4414, \operatorname{csg} A:: \operatorname{Tn} 5-132$ SLS205 & Kroos and Kaiser (1987) \\
\hline DK5296 & $\operatorname{csg} A:: \operatorname{Tn} 5-132 \Omega$ LS205, Tn5 lac $\Omega 4491$ & Kroos and Kaiser (1987) \\
\hline DK7516 & Tn5 lac $\Omega 7516$ & $\mathrm{P} 1:: \operatorname{Tn} 5$ lac $\rightarrow \mathrm{DK} 1622^{\mathrm{a}}$ \\
\hline DK7522 & Tn5 lac $\Omega 7522$ & $\mathrm{P} 1:: \operatorname{Tn} 5$ lac $\rightarrow$ DK1622a \\
\hline DK7540 & Tn5 lac $\Omega 7540$ & $\mathrm{Pl}:: \operatorname{Tn} 5 \mathrm{lac} \rightarrow \mathrm{DK} 1622^{\mathrm{a}}$ \\
\hline DK7546 & Tn5 lac $\Omega 7546$ & $\mathrm{Pl}:: \operatorname{Tn} 5 \mathrm{lac} \rightarrow \mathrm{DK} 1622^{\mathrm{a}}$ \\
\hline DK7632 & Tn5 lac $\Omega 7632$ & $\mathrm{Pl}:: \operatorname{Tn} 5 \mathrm{lac} \rightarrow \mathrm{DK} 1622^{\mathrm{a}}$ \\
\hline DK7663 & Tn5 lac $\Omega 7663$ & $\mathrm{Pl}:: \operatorname{Tn} 5 \mathrm{lac} \rightarrow \mathrm{DK} 1622^{\mathrm{a}}$ \\
\hline DK7677 & Tn5 lac $\Omega 7677$ & $\mathrm{Pl}:: \operatorname{Tn} 5 \mathrm{lac} \rightarrow \mathrm{DK} 1622^{\mathrm{a}}$ \\
\hline DK8505 & frzCD::Tn5 lac $\Omega 536$ & Sager and Kaiser (1994) \\
\hline DK8506 & frzCD::Tn5 $\Omega 224$ & Sager and Kaiser (1994) \\
\hline DK9032 & $\Delta f r z\left(A^{\prime}-E^{\prime}\right):: \operatorname{Kan}^{\mathrm{r}}$ & $\mathrm{Mx} 8(\mathrm{DZF} 3558) \rightarrow \mathrm{DK} 1622^{\mathrm{a}}$ \\
\hline DK9033 & $\Delta f_{r z}\left({ }^{\prime} C D-F\right):: \operatorname{Kan}^{\mathrm{r}}$ & $\mathrm{Mx} 8(\mathrm{DZF} 4059) \rightarrow \mathrm{DK} 1622^{\mathrm{a}}$ \\
\hline DK9034 & $\operatorname{csg} A:: \operatorname{Tn} 5-132 \Omega \operatorname{LS} 205, \Delta f r z\left(A-E^{\prime}\right):: \operatorname{Kan}^{\mathrm{r}}$ & Mx8(DZF3558) $\rightarrow$ DK5208 \\
\hline DK9035 & $\operatorname{csg} A:: \operatorname{Tn} 5-132 \Omega \mathrm{LS} 205, \Delta f r z\left({ }^{\prime} C D-F\right):: \mathrm{Kan}^{\mathrm{r}}$ & Mx8(DZF4059) $\rightarrow$ DK5208 \\
\hline DK9036 & $\operatorname{csg} A:: \operatorname{Tn} 5-132 \Omega \mathrm{LS} 205$, frzCD::Tn5 $\Omega 224$ & Mx8(DZF3460) $\rightarrow$ DK5208 \\
\hline DK9037 & $\operatorname{csg} A:: \operatorname{Tn} 5-132 \Omega \mathrm{LS} 205$, frz CD::Tn5 lac 2536 & Mx8(DZF3591) $\rightarrow$ DK5208 \\
\hline DK9038 & Tn5 lac $\Omega 4499$, frzE::Tn5(Tet $\left.{ }^{r}\right) \Omega 231$ & Mx8(DZF4041) $\rightarrow$ DK4499a \\
\hline DK9039 & $\operatorname{Tn} 5$ lac $\Omega 4414$, frzE::Tn5(Tet $\left.{ }^{r}\right) \Omega 231$ & Mx8(DZF4041) $\rightarrow$ DK5279a \\
\hline DK9040 & $\operatorname{Tn} 5$ lac $\Omega 4403$, frzE::Tn5(Tet $\left.{ }^{r}\right) \Omega 231$ & Mx8(DZF4041) $\rightarrow$ DK4368 \\
\hline DK9041 & $\operatorname{Tn} 5$ lac $\Omega 4401$, frzE::Tn5( Tet $\left.^{r}\right) \Omega 231$ & $\mathrm{Mx} 8(\mathrm{DZF} 4041) \rightarrow \mathrm{DK} 4293^{\mathrm{a}}$ \\
\hline DK9042 & $\operatorname{Tn} 5$ lac $\Omega 4435$, frzE::Tn5(Tet $\left.{ }^{r}\right) \Omega 231$ & Mx8(DZF4041) $\rightarrow$ DK5204 $^{a}$ \\
\hline DK9043 & Tn5 lac $\Omega 4499$, frzCD::Tn5( Tet $\left.^{r}\right) \Omega 224$ & Mx8(DZF4042) $\rightarrow$ DK4499 \\
\hline DK9044 & $\operatorname{Tn} 5$ lac $\Omega 4414$, frz $C D:: \operatorname{Tn} 5\left(\right.$ Tet $\left.^{r}\right) \Omega 224$ & Mx8(DZF4042) $\rightarrow$ DK5279a \\
\hline DK9045 & Tn5 lac $\Omega 4403$, frz $C D:: \operatorname{Tn} 5\left(\right.$ Tet $\left.^{\mathrm{r}}\right) \Omega 224$ & $\mathrm{Mx} 8(\mathrm{DZF} 4042) \rightarrow \mathrm{DK} 4368^{\mathrm{a}}$ \\
\hline DK9046 & Tn5 lac $\Omega 4401$, frz $C D:: \operatorname{Tn} 5\left(\right.$ Tet $\left.^{\text {r }}\right) \Omega 224$ & $\mathrm{Mx} 8(\mathrm{DZF} 4042) \rightarrow \mathrm{DK} 4293^{\mathrm{a}}$ \\
\hline DK9047 & Tn5 lac $\Omega 4435$, frzCD::Tn5(Tet $\left.{ }^{\mathrm{r}}\right) \Omega 224$ & $\mathrm{Mx} 8(\mathrm{DZF} 4042) \rightarrow \mathrm{DK} 5204^{\mathrm{a}}$ \\
\hline DK9048 & $\operatorname{csg} A:: \operatorname{Tn} 5-132 \Omega \operatorname{LS} 205$, frzE::Tn5 $\Omega 226$ & Mx8(DK9711) $\rightarrow$ DK5208 $^{a}$ \\
\hline DK9049 & Tn5 lac $\Omega 7540$, frzE::Tn5(Tet $\left.{ }^{\mathrm{r}}\right) \Omega 231$ & $\mathrm{Mx} 8(\mathrm{DZF} 4041) \rightarrow \mathrm{DK} 11063^{\mathrm{a}}$ \\
\hline DK9050 & Tn5 lac $\Omega 7540$, frzCD::Tn5(Tet $\left.{ }^{\mathrm{r}}\right) \Omega 224$ & $\mathrm{Mx} 8(\mathrm{DZF} 4042) \rightarrow \mathrm{DK} 11063^{\mathrm{a}}$ \\
\hline DK9711 & frzE::Tn5 $\Omega 226$ & A. Spormann (Stanford University, Palo Alto, California) \\
\hline DK1 1015 & Tn5 lac $\Omega 7516$ & $\mathrm{Mx} 4(\mathrm{DK} 7516) \rightarrow \mathrm{DK} 1622^{\mathrm{a}}$ \\
\hline DK1 1016 & Tn5 lac $\Omega 7522$ & $\mathrm{Mx} 4(\mathrm{DK} 7522) \rightarrow \mathrm{DK} 1622^{\mathrm{a}}$ \\
\hline DK 11018 & Tn5 lac $\Omega 7632$ & $\mathrm{Mx} 4(\mathrm{DK} 7632) \rightarrow \mathrm{DK} 1622^{\mathrm{a}}$ \\
\hline DK11019 & Tn5 lac $\Omega 7663$ & $\mathrm{Mx} 4(\mathrm{DK} 7663) \rightarrow \mathrm{DK} 1622^{\mathrm{a}}$ \\
\hline DK1 1020 & Tn5 lac $\Omega 7677$ & $\mathrm{Mx} 4(\mathrm{DK} 7677) \rightarrow \mathrm{DK} 1622^{\mathrm{a}}$ \\
\hline DK1 1049 & $\operatorname{csg} A:: \operatorname{Tn} 5-132 \Omega$ LS205, Tn5 lac $\Omega 7516$ & $\mathrm{Mx} 4(\mathrm{DK} 7516) \rightarrow \mathrm{DK} 5208^{\mathrm{a}}$ \\
\hline DK11050 & $\operatorname{csg} A:: \operatorname{Tn} 5-132 \Omega$ LS205, Tn5 lac $\Omega 7522$ & $\mathrm{Mx} 4(\mathrm{DK} 7522) \rightarrow \mathrm{DK}^{2} 28^{\mathrm{a}}$ \\
\hline DK1 1051 & $\operatorname{csg} A:: \operatorname{Tn} 5-132 \Omega \mathrm{LS} 205, \operatorname{Tn} 5$ lac $\Omega 7546$ & $\mathrm{Mx} 4(\mathrm{DK} 7546) \rightarrow \mathrm{DK}^{2} 208^{\mathrm{a}}$ \\
\hline DK11053 & $\operatorname{csg} A:: \operatorname{Tn} 5-132 \Omega$ LS205, Tn5 lac $\Omega 7632$ & $\mathrm{Mx} 4(\mathrm{DK} 7632) \rightarrow \mathrm{DK}^{2} 208^{\mathrm{a}}$ \\
\hline DK11054 & $\operatorname{csg} A:: \operatorname{Tn} 5-132$ SLS205, Tn5, lac $\Omega 7663$ & Mx4(DK7663) $\rightarrow$ DK5208 $^{a}$ \\
\hline DK11055 & $\operatorname{csg} A:: \operatorname{Tn} 5-132 \Omega$ LS205, Tn5 lac $\Omega 7677$ & $\mathrm{Mx} 4(\mathrm{DK} 7677) \rightarrow$ DK5208 \\
\hline DK11063 & Tn5 lac $\Omega 7540$ & $\mathrm{Mx} 4(\mathrm{DK} 7540) \rightarrow \mathrm{DK} 1622^{\mathrm{a}}$ \\
\hline DK1 1064 & Tn5 lac $\Omega 7546$ & $\mathrm{Mx} 4(\mathrm{DK} 7546) \rightarrow \mathrm{DK}^{2622^{\mathrm{a}}}$ \\
\hline DK11074 & $\operatorname{csg} A:: \operatorname{Tn} 5-132 \Omega$ LS205, Tn5 lac $\Omega 7540$ & $\mathrm{Mx} 4(\mathrm{DK} 7540) \rightarrow \mathrm{DK}^{2} 208^{\mathrm{a}}$ \\
\hline DK11075 & $\operatorname{Tn} 5 \operatorname{lac}\left(\right.$ Tet $\left.^{\mathrm{r}}\right) \Omega 4491$ & P1::Tn5-132 $\rightarrow$ DK5285 \\
\hline DZF3460 & $s g l A 1$, frzCD::Tn5 $\Omega 224$ & McCleary et al. (1990) \\
\hline
\end{tabular}


Table 7. (Continued)

\begin{tabular}{lll}
\hline Strain & Relevant genotype & Reference or source \\
\hline DZF3558 & sglA1, $\Delta$ frz $\left(A-E^{\prime}\right):: \operatorname{Kan}^{\mathrm{r}}$ & Blackhart and Zusman $(1985 \mathrm{a})$ \\
DZF3591 & sglA1, frzCD::Tn5 $\operatorname{lac} \Omega 536$ & Weinberg and Zusman $(1989)$ \\
DZF4041 & sglA1, frzE::Tn5(Tet) $\Omega 231$ & D. Zusman (University of California, Berkeley) \\
DZF4042 & sglA1, frzCD::Tn5(Tet $\left.{ }^{r}\right) \Omega 224$ & D. Zusman \\
DZF4059 & sglA1, $\Delta f r z\left({ }^{\prime} C D-F\right):: \operatorname{Kan}^{\mathrm{r}}$ & McBride et al. (1992) \\
\hline
\end{tabular}

${ }^{\mathrm{a}} \mathrm{Mx} 4$ and $\mathrm{Mx} 8$ are abbreviations for $\mathrm{Mx} 4 \mathrm{ts} 18 \mathrm{ts} 27 \mathrm{hrm}$ and $\mathrm{Mx} 8 \mathrm{clp} 2 \mathrm{ts} 3$, respectively. Phage were grown on the indicated strains and transduced $(\rightarrow)$ to the indicated recipient strain with selection for the antibiotic resistance marker present at the Tn5 element.

different responses to extracellular cAMP (chemotaxis, early aggregation, and cell differentiation) are mediated by at least four different cAMP receptors (Devreotes 1994). In light of the parallels, what of the possibility that the C-factor signal might be processed through different sensors? Although this possibility cannot be ruled out entirely by the available data, the block imposed by the class II mutations on all C-factor-dependent activities-rippling and aggregation, which are early events, as well as sporulation, which is a late event-leads to the simple view embodied in Figure 6 that the C-factor signal is received by a single sensor that is common to all four responses.

Although aggregation normally precedes sporulation in fruiting body development, and many aggregation-defective mutants (such as $\operatorname{asg} A$, asg $B$, and asgC) are sporulation defective, other published data suggest that sporulation does not lie at the end of a linearly dependent aggregation pathway. For example, several mutants with severe aggregation defects have been isolated that sporulate at high levels (Morrison and Zusman 1979; Rhie and Shimkets 1989/. Likewise, addition of purified C-factor to nonmotile cells ( $\mathrm{mglA}$ or $\mathrm{A}^{-} \mathrm{S}^{-}$) restores sporulation without restoring the capacity to aggregate (Kim and Kaiser 1991). This uncoupling of aggregation and sporulation has led previously to the suggestion that the two processes result from two independent parallel pathways (Morrison and Zusman 1979; Rhie and Shimkets 1989). However, the data presented here together with the lines of evidence listed below imply that the two processes are not independent and suggest that the uncoupling of the two processes in several mutants might be understood within the context of a branched C-factor signaling pathway, like Figure 6. Starvation induces both aggregation and sporulation (Manoil and Kaiser 1980), A-signaling precedes and is required for both aggregation and sporulation, and C-signaling is required for and occurs concomitant with both aggregation and sporulation (Kaiser and Losick 1993). Mutations that interfere with starvation recognition (Manoil 1978), A-signaling or C-signaling prevent both aggregation and sporulation (Kaiser and Losick 1993). These observations imply that aggregation and sporulation proceed through a common pathway that depends on proper starvation recognition, A-signaling and C-signaling. The data presented in this report demonstrate that uncoupling of aggregation and sporulation can occur downstream of the C-factor signaling event (i.e., the common developmental pathway has a bifurcation downstream of this event). The normal confinement of spores to fruiting bodies or to their immediate neighborhood, however, implies that the two branches in the C-factor signaling pathway of Figure 6 are cross-connected, thus coordinating the two processes during this stage of fruiting body formation. Although it is premature to draw specific cross-connections, some deductions can be made. The uncoupling of aggregation and sporulation in the frz mutants suggests that in wildtype cells sporulation may be inhibited either directly or indirectly by an element in the aggregation pathway. As normal aggregation proceeds, the inhibition would be alleviated, and sporulation would then follow. In this framework, sporulation by the frz mutants can be explained by an absence from the start of the putative sporulation inhibitor. Interestingly, a higher concentration of C-factor is required to initiate sporulation than to initiate aggregation (Kim and Kaiser 1991; Li et al. 1992). Thus one candidate for the trigger that relieves the inhibition of sporulation is an elevation of the level of C-factor signaling.

How does C-factor induce rippling and aggregation? The frz genes encode homologs of the proteins involved in the chemotactic response of enteric bacteria (McBride et al. 1989; McCleary and Zusman 1990; McCleary et al. 1990), and are involved in controlling the single cell reversal frequency (Blackhart and Zusman 1985b; McCleary et al. 1990; McBride et al. 1992). It has been hypothesized that the Frz proteins constitute a signal transduction system that regulates the single cell reversal frequency in response to environmental cues (McBride et al. 1992; Shi et al. 1993). The FrzCD protein contains a region homologous to the carboxy-terminal portion of the methyl-accepting chemotaxis proteins, or MCPs (McBride et al. 1989). FrzCD undergoes methylation and demethylation in response to various stimuli (McCleary et al. 1990; McBride et al. 1992; McBride and Zusman 1993; Shi et al. 1993) and displays a reduced level of methylation in a $\operatorname{csg} A$ mutant compared with a wildtype strain during development (McBride and Zusman 1993). FrzCD is a cytoplasmic protein that lacks homology to the amino-terminal extracellular domain and the two membrane spanning segments of the MCPs (McBride et al. 1989, 1992), thus arguing against the idea that FrzCD is a cell-surface exposed C-factor sensor. Rather FrzCD and other Frz proteins would act downstream of the sensor and the class II component in a branch of the signaling pathway devoted to control of cell movement 
as shown in the model of Figure 6. Evidence that $\mathrm{C}$-factor signaling increases FrzCD methylation in a class II dependent manner is reported separately (Søgaard-Andersen and Kaiser 1996). These results support the location of class II between the signaling event and the Frz proteins. Moreover, they suggest that $\mathrm{C}$-factor acts as a cellbound signal, which is transduced by the Frz signal transduction system to regulate the frequency of cell reversals during aggregation and rippling. Sager and Kaiser (1994) showed that the Frz proteins are necessary for the propagation of ripples. Furthermore they provided evidence that addition of partially purified $\mathrm{C}$-factor changes the reversal frequency of starving $M$. xanthus cells located outside fruiting bodies. Both effects are consistent with the pathway shown in Figure 6.

Recently, an amino acid sequence similarity between $\mathrm{C}$-factor and the family of short chain alcohol dehydrogenases was pointed out (Baker 1994; Lee and Skimkets 1994). Therefore, the question arises whether $C$-factor is the signal molecule that activates the $\mathrm{C}$-signaling pathway in a responding cell, or C-factor acts as an enzyme that produces a signal molecule that activates the pathway, or whether the putative enzymatic activity of $\mathrm{C}$-factor modifies a cell-surface component and then that modification serves as the signal that is transmitted to the interior of the cell. C-factor signaling apparently requires cell-cell contact (Kim and Kaiser 1990a). All three modes of action are compatible both with this requirement as well as with the model in Figure 6. Further experiments are required to distinguish between these possibilities.

A loss-of-function mutation in the gene encoding an extracellular signal often results in a phenotype that is similar to that conferred by mutations in genes coding for components in the downstream signaling pathway. For example, mutations in genes of the Drosophila wingless signaling pathway have phenotypes very similar to that of a wingless mutation (Noordermeer et al. 1994; Siegfried et al. 1994). In another case, Delta was discovered as the signal for Notch among mutants with the same developmental block as a Notch mutant (Artavanis-Tsakonas and Simpson 1992). The same logic was applied to identify genes involved in C-factor signal transduction in $M$. xanthus. A collection of developmental mutants was screened for those that displayed abnormal aggregation, one of the earliest defects in a $\operatorname{csg} A$ mutant. The versatility of this screening procedure is that potentially it allows one to identify the earliest acting components in the $\mathrm{C}$-factor signal transduction pathway. The fact that 7 of 8 Tn 5 lac insertion mutants found using this strategy have Tn5 lac inserted in genes in the $\operatorname{csg} A$ pathway demonstrates the feasibility of this approach to map signaling pathways in $M$. xanthus.

\section{Materials and methods}

Strains

M. xanthus strains used are listed in Table 7.

\section{General methods}

M. xanthus and Escherichia coli were grown as described (Thöny-Meyer and Kaiser 1993). Generalized transductions with myxophage $\mathrm{Mx} 4 t s 18 t s 27 \mathrm{hrm}$ and $\mathrm{Mx} 8 \mathrm{clp} 2 \mathrm{ts} 3$ were done as described (Avery and Kaiser 1983; Stephens and Kaiser 1987), respectively. All strains constructed by generalized transduction had at least two isolates analyzed by Southern blot analysis to check that the transferred marker had integrated at the correct position and had the correct structure. When required for a genetic construction, the aphII gene on Tn5 lac that confers $\mathrm{Kan}^{\mathrm{r}}$ was replaced with the gene conferring $\mathrm{Tet}^{\mathrm{r}}$ fromTn5-132 as described (Avery and Kaiser 1983).

Aggregation, sporulation, extracellular complementation, rippling, and motility assays

The aggregation phenotypes were monitored on TPM [10 $\mathrm{mM}$ Tris- $\mathrm{HCl}(\mathrm{pH} 7.5), 1 \mathrm{~mm} \mathrm{KH} \mathrm{PO}_{4}, 8 \mathrm{~mm} \mathrm{MgSO}$ ] $1.5 \%$ agar plates. Briefly, cells were grown to a density of Klett $100\left(5 \cdot 10^{8}\right.$ cells $/ \mathrm{ml}$ ) in CTT medium, harvested, and resuspended in TPM buffer at a calculated density of 1000 Klett units. Twentymicroliter aliquots of the cell suspension were spotted on TPM agar plates and incubated at $32^{\circ} \mathrm{C}$. Aggregation was followed visually with an inverted microscope (Leitz Labovert, Wetzlar, Germanyl equipped with a long-working-distance condensor and phase contrast objectives, or with a Leica Orthoplan microscope in bright field without a condensor and with a $\times 1$ objective. Starvation-induced sporulation was measured in submerged culture (Kuner and Kaiser 1982). Briefly, cells were grown to a density of 100 Klett units in CTT medium, harvested, and resuspended in MC7 [10 mM morpholinepropanesuonic acid, $(\mathrm{pH} 7.0), 1 \mathrm{mM} \mathrm{CaCl}_{2}$ ) to a calculated density of $1000 \mathrm{Klett}$ units. Twenty five-microliter aliquots of these suspensions were mixed with $375 \mu \mathrm{l}$ of $\mathrm{MC} 7$, transferred to a microtiter well with a diameter of $15 \mathrm{~mm}$, and incubated in a humid chamber for $72 \mathrm{hr}$ at $32^{\circ} \mathrm{C}$. Development was followed visually as described above. Spore titers were determined by transferring the cells from a well to a microfuge tube containing $400 \mu \mathrm{l}$ of $\mathrm{MC}$, followed by sonication for $15 \mathrm{sec}$ at $30 \%$ output capacity with a standard microtip, 5 min of sonication in a cup horn with ice water cooling, and incubation at $50^{\circ} \mathrm{C}$ for $2 \mathrm{hr}$. After serial dilution of the samples, $10-\mu \mathrm{l}$ aliquots were plated on CTT agar with or without antibiotics as indicated. Spores were counted as colonies after 3-5 days of incubation at $32^{\circ} \mathrm{C}$ to allow germination and growth to occur. If no colonies were observed after 5 days of incubation at $32^{\circ} \mathrm{C}$, a $100-\mu \mathrm{l}$ aliquot of cells harvested from a well and treated as described was plated on CTT agar with or without antibiotics as indicated to obtain a more precise estimate of the sporulation frequency. To check for extracellular C-factor complementation, 12.5- $\mu$ l aliquots of cells in MC7 at a density of 1000 Klett units were mixed, transferred to $375 \mu \mathrm{l}$ of MC7, placed in a microtiter well, and incubated at $32^{\circ} \mathrm{C}$ for $72 \mathrm{hr}$ as described. Spore titers were then measured as described. The ability of strains to form ripples was observed on CF agar plates (Shimkets and Kaiser 1982a). Cells prepared as in the sporulation assay were spotted in 10- $\mu$ l aliquots on CF agar plates and incubated at $32^{\circ} \mathrm{C}$. The plates were scanned visually over the next $48 \mathrm{hr}$. Motility was tested by spotting $10-\mu \mathrm{l}$ aliquots of cell suspensions at a calculated density of 1000 Klett units in TPM buffer on 1/2CTT agar (Hodgkin and Kaiser 1979b) and incubating at $32^{\circ} \mathrm{C}$. Motility mutants were detected by their failure to spread (swarm) to the same degree as the fully motile strain DK1622. 


\section{Tn5 lac mutagenesis}

Tn5 lac was introduced into the fully motile DK1622 by P1mediated transduction (Kroos and Kaiser 1984). Kan ${ }^{\mathrm{r}}$ transductants were picked to fresh CTT + Kan plates. Approximately 10,000 transductants were examined for increased lacZ expression during development over a 3-day period of fruiting body development after regrowth on CTT plates. A loopfull of vegetatively growing cells was transferred from the CTT agar to TPM agar plates containing $40 \mu \mathrm{g} / \mathrm{ml}$ of X-gal (5-bromo-4chloro-3-indolyl- $\beta$-D-galactopyranoside) and to CTT agar plates containing $20 \mu \mathrm{g} / \mathrm{ml} \mathrm{X}$-gal. Levels of $\beta$-galactosidase activity were estimated by comparing the intensity of indigo blue dye deposited by developing cells versus vegetatively growing cells. Aggregation, sporulation, and motility defects were detected visually in a dissecting microscope. Altogether, 273 mutants displaying increased lacZ expression during development, developmental defects, or motility defects were retained. Among the 273 mutants, 42 displayed abnormal development and were analyzed in more detail in this report.

\section{Physical mapping of Tn5 lac insertions}

Chromosomal DNA was isolated as described (Avery and Kaiser 1983) and independent digests prepared with the indicated restriction enzymes (Fig. 2). Southern blotting followed published procedures (Sambrook et al. 1989). A probe specific for the 5' end of lacZ was isolated from pLRK3l (Kroos et al. 1986) that contains the 3.4-kbp BamHI-EcoRI fragment of the left-side of Tn5 lac including the $5^{\prime}$ end of lacZ. The restriction fragment containing the entire $f_{r z}$ locus isolated from pBB12 (Blackhart and Zusman 1985a) was used as the $f r z$ specific probe. A probe specific for the region immediately upstream of $\Omega 7540$ was isolated from pFS703, obtained as follows. Chromosomal DNA from DK1 1063 that contains $\Omega 7540$ was digested with SalI and DNA fragments with sizes of $10-15 \mathrm{kbp}$ isolated from an agarose gel (SalI has one restriction site in Tn 5 lac, $\sim 9 \mathrm{kbp}$ from the left-most end of Tn5 lac and one site $3.3-\mathrm{kbp}$ upstream of $\Omega 7540$. These Sall fragments were ligated into the SalI site in pBluescript II SK ${ }^{+}$(Stratagene) and transformed into $E$. coli JM106 [e14- (McrA $\left.\left.^{-}\right)\right]$, endA1, hsdR17, gyrA96, thi-1, supE44, relA1, $\triangle$ (lac-proAB) (Yanisch-Perron et al. 1985) with selection for $\mathrm{Ap}^{\mathrm{r}}$ and $\mathrm{Kan}^{\mathrm{r}}$. The plasmid containing the correct Sall fragment was denoted pFS700. Subsequently, the BamHI fragment containing the entire left-most end of Tn 5 lac, except for $54 \mathrm{bp}$ of the left IS50 sequence, was deleted from pFS700 generating pFS703 that contains $54 \mathrm{bp}$ of the left end of IS50 and $3.3 \mathrm{kbp}$ of $M$. xanthus DNA upstream of $\Omega 7540$. To confirm that pFS700 and pFS703 contained the DNA upstream of $\Omega 7540$, the $M$. $x$ anthus DNA from either plasmid was shown by Southern blotting to hybridize to the same restriction fragments from DKl 1063 as a lacZ specific probe.

\section{Measurement of $\beta$-galactosidase activity}

Cells were induced to develop under submerged conditions as described in the sporulation assay. At the indicated times, cells from a well were harvested into $0.4 \mathrm{ml}$ of MC7 and stored at $-20^{\circ} \mathrm{C}$ until all were collected. Samples were sonicated $15 \mathrm{sec}$ with a standard microtip (Heat Systems-Ultrasonics) and then 5 min in a cup horn (Tekmar) with ice-water cooling. Otherwise quantitation of $\beta$-galactosidase specific activity was performed as described (Kroos et al. 1986) except that $\beta$-mercaptoethanol was omitted from the Z-buffer and that samples were not sedimented before they were assayed.

\section{Acknowledgments}

We thank David Zusman and Alfred Spormann for providing plasmid and strains, Greg Marczynski for helpful comments on the manusccript, and members of D. Kaiser's laboratory for helpful discussions and comments. This investigation was supported by U.S. Public Health Service grant GM 23441 to D.K. from the National Institute of General Medical Sciences, and a stipend to L. S.-A. from the Danish Natural Science Research Council.

The publication costs of this article were defrayed in part by payment of page charges. This article must therefore be hereby marked "advertisement" in accordance with 18 USC section 1734 solely to indicate this fact.

\section{References}

Arias, A.M. 1994. Pathways of cell communication during development: Signalling and epistases. Trends Genet 10: 219222.

Artavanis-Tsakonas, S. and P. Simpson. 1992. Choosing a cell fate: A view from the Notch locus. Trends Genet. 7: 403408

Avery, L. and D. Kaiser. 1983. In situ transposon replacement and isolation of a spontaneous tandem genetic duplication. Mol. \& Gen. Genet. 191: 99-109.

Avery, L. and S. Wasserman. 1992. Ordering gene function: The interpretation of epistasis in regulatory hierarchies. Trends Genet. 8: 312-316.

Baker, M. 1994. Myxococcus xanthus C-factor, a morphogenic paracrine signal, is similar to E. coli 3 -ketoacyl-acyl carrier protein reductase and human $17 \beta$-hydroxysteroid dehydrogenase. Biochem. J. 301: 311-312.

Blackhart, B.D. and D.R. Zusman. 1985a. Cloning and complementation analysis of the "Frizzy" genes of Myxococcus xanthus. Mol. \& Gen. Genet. 198: 243-254.

. 1985b. "Frizzy" genes of Myxococcus xanthus are involved in control of frequency of reversal of gliding motility. Proc. Natl. Acad. Sci. 82: 8767-8770.

Chen, H., A. Kuspa, I.M. Keseler, and L.J. Shimkets. 1991. Physical map of the Myxococcus xanthus chromosome. I. Bacteriol. 173: 2109-2115.

Devreotes, P.N. 1994. G protein-linked signaling pathways control the developmental program of Dictyostelium. Neuron 12: $235-241$.

Gross, J.D. 1994. Developmental decisions in Dictyostelium discoideum. Microbiol. Rev. 58: 330-351.

Hagen, T.J., and L.J. Shimkets. 1990. Nucleotide sequence and transcriptional products of the csg locus of Myxococcus xanthus. J. Bacteriol. 172: 15-23.

He, Q., H. Chen, A. Kuspa, Y. Cheng, D. Kaiser, and L.J. Shimkets, 1994. A physical map of the Myxococcus xanthus chromosome. Proc. Natl. Acad. Sci. 91: 9584-9587.

Hodgkin, J. and D. Kaiser. 1979a. Genetics of gliding motility in Myxococcus xanthus (Myxobacterales): Genes controlling movement of single cells. Mol. \& Gen. Genet. 171: 167-176.

- 1979b. Genetics of gliding motility in Myxococcus xanthus (Myxobacterales): Two gene systems control movement. Mol. \& Gen. Genet. 171: 177-191.

Kaiser, D. 1979. Social gliding is correlated with the presence of pili in Myxococcus xanthus. Proc. Natl. Acad. Sci. 76: 59525956.

- 1993. Roland Thaxter's legacy and the origins of multicellular development. Genetics 135: 249-254.

Kaiser, D. and R. Losick. 1993. How and why bacteria talk to each other. Cell 73: 873-885. 
Kashefi, K. and P.L. Hartzell. 1995. Genetic suppression and phenotypic masking of a Myxococcus xanthus frzF defect. Mol. Microbiol. 15: 483-494.

Kim, S.K. and D. Kaiser. 1990a. C-factor: A cell-cell signaling protein required for fruiting body morphogenesis of $M$. xanthus. Cell 61: 19-26.

1990b. Cell motility is required for the transmission of $C$-factor, an intercellular signal that coordinates fruiting body morphogenesis of Myxococcus xanthus. Genes \& Dev. 4: 896-904.

- 1990c. Purification and properties of Myxococcus xanthus C-factor, an intercellular signaling protein. Proc. Natl. Acad. Sci. 87: 3635-3639.

- 1990d. Cell alignment required in differentiation of Myxococcus xanthus. Science 249: 926-928.

- 1991. C-factor has distinct aggregation and sporulation thresholds during Myxococcus development. I. Bacteriol. 173: 1722-1728.

Kim, S.K., D. Kaiser, and A. Kuspa. 1992. Control of cell density and pattern by intercellular signaling in Myxococcus development. Annu. Rev. Microbiol. 46: 117-139.

Kroos, L. and D. Kaiser. 1984. Construction of Tn5 lac, a transposon that fuses lac $Z$ expression to exogenous promoters, and its introduction into Myxococcus xanthus. Proc. Natl. Acad. Sci. 81: 5816-5820.

1987. Expression of many developmentally regulated genes in Myxococcus depends on a sequence of cell interactions. Genes \& Dev. 1: 840-854.

Kroos, L., A. Kuspa, and D. Kaiser. 1986. A global analysis of developmentally regulated genes in Myxococcus xanthus. Dev. Biol. 117: 252-266.

Kroos, L., P.L. Hartzell, K. Stephens, and D. Kaiser. 1988. A link between cell movement and gene expression argues that motility is required for cell-cell signaling during fruiting body development. Genes \& Dev. 2: 677-1685.

Kroos, L., A. Kuspa, and D. Kaiser. 1990. Defects in fruiting body development caused by Tn5 lac insertions in Myxococcus xanthus. I. Bacteriol. 172: 484-487.

Kuner, J.M. and D. Kaiser. 1982. Fruiting body morphogenesis in submerged cultures of Myxococcus xanthus. I. Bacteriol. 151: 458-461.

Lee, K. and L.J. Shimkets. 1994. Cloning and characterization of the socA locus which restores development to Myxococcus xanthus C-signaling mutants. J. Bacteriol. 176: 2200-2209.

Li, S., B.U. Lee, and L.J. Shimkets. 1992. csgA expression entrains Myxococcus xanthus development. Genes \& Dev. 6: $401-410$.

Manoil, C.C. 1978. "Initiation of development in Myxococcus xanthus." Ph.D. thesis, Stanford University, Stanford, CA.

Manoil, C.C. and D. Kaiser. 1980. Guanosine pentaphosphate and guanosine tetraphosphate accumulation and induction of Myxococcus xanthus fruiting body development. I. Bacteriol. 141: 305-315.

McBride, M.J. and D.R. Zusman. 1993. FrzCD, a methyl-accepting taxis protein from Myxococcus xanthus, shows modulated methylation during fruiting body formation. $/$. Bacteriol. 175: 4936-4940.

McBride, M.J., R.A. Weinberg, and D.R. Zusman. 1989. "Frizzy" aggregation genes of the gliding bacterium Myxococcus xanthus show sequence similarities to the chemotaxis genes of enteric bacteria. Proc. Natl. Acad. Sci. 86: 424-428.

McBride, M.J., T. Köhler, and D.R. Zusman. 1992. Methylation of FrzCD, a methyl-accepting taxis protein of Myxococcus xanthus, is correlated with factors affecting cell behaviour. $J$. Bacteriol. 174: 4246-4257.

McCleary, W.R. and D.R. Zusman. 1990. FrzE of Myxococcus xanthus is homologous to both CheA and CheY of Salmonella typhimurium. Proc. Natl. Acad. Sci. 87: 5898-5902.

McCleary, W.R., M.J. McBride, and D.R. Zusman. 1990. Developmental sensory transduction in Myxococcus xanthus involves methylation and demethylation of FrzCD. J. Bacteriol. 172: 4877-4887.

Morrison, C.E. and D.R. Zusman. 1979. Myxococcus xanthus mutants with temperature-sensitive, stage-specific defects: Evidence for independent pathways in development. I. Bacteriol. 140: 1036-1042.

Noordermeer, J., J. Klingensmith, N. Perrimon, and R. Nusse. 1994. dishevelled and armadillo act in the Wingless signalling pathway in Drosophila. Nature 367: 80-83.

Rhie, H.G. and L.J. Shimkets. 1989. Developmental bypass suppression of Myxococcus xanthus csgA mutations. I. Bacteriol. 171: 3268-3276.

Sager, B. and D. Kaiser. 1993. Two cell-density domains within the Myxococcus xanthus fruiting body. Proc. Natl. Acad. Sci. 90: 3690-3694

1994. Intercellular C-signaling and the traveling waves of Myxococcus. Genes \& Dev. 8: 2793-2804.

Sambrook, J., E.F. Fritsch, and T. Maniatis. 1989. "Molecular cloning. A laboratory manual", Cold Spring Harbor Laboratory Press, Cold Spring Harbor, NY.

Shi, W., T. Köhler, and D.R. Zusman. 1993. Chemotaxis plays a role in the social behaviour of Myxococcus xanthus. Mol. Microbiol. 9: 601-611.

Shimkets, L.J. 1990. Social and developmental biology of the myxobacteria. Microbiol Rev. 54: 473-501.

Shimkets, L.J. and S.J. Asher. 1988. Use of recombination techniques to examine the structure of the csg locus of Myxococcus xanthus. Mol. Gen. Genet. 211: 63-71.

Shimkets, L.J. and D. Kaiser. 1982a. Induction of coordinated movement of Myxococcus xanthus cells. I. Bacteriol. 152: $451-461$

- 1982b. Murein components rescue developmental sporulation of Myxococcus xanthus. J. Bacteriol. 152: 462470.

Shimkets, L.J. and H. Rafiee. 1990. CsgA, an extracellular protein essential for Myxococcus xanthus development. I. Bacteriol. 172: 5299-5306.

Shimkets, L.J., R.E. Gill, and D. Kaiser. 1983. Developmental cell interactions in Myxococcus xanthus and the spoC locus. Proc. Natl. Acad. Sci. 80: 1406-1410.

Siegfried, E., E. Wilder, and N. Perrimon. 1994. Components of wingless signalling in Drosophila. Nature 367: 76-80.

Søgaard-Andersen, L. and D. Kaiser. 1996. C-factor, a cell-surface associated intercellular signaling protein, stimulates the cytoplasmic Frz signal transduction system in $M$. xanthus. Proc. Natl. Acad. Sci. (in press).

Stephens, K. and D. Kaiser. 1987. Genetics of gliding motility in Myxococcus xanthus: Molecular cloning of the $m g l$ locus. Mol. \& Gen. Genet. 207: 256-266.

Thöny-Meyer, L. and D. Kaiser. 1993. devRS, an auto regulated and essential genetic locus for fruiting body development in Myxococcus xanthus. J. Bacteriol. 175: 7450-7462.

Weinberg, R.A. and D.R. Zusman. 1989. Evidence that the Myxococcus xanthus frz genes are developmentally regulated. I. Bacteriol. 171: 6174-6186.

Yanisch-Perron, C., J. Vieira, and J. Messing. 1985. Improved M13 phage cloning vectors and host strains: Nucleotide sequence of the M13mp18 and pUC19 vectors. Gene 33: 103119.

Zusman, D.R. 1982. "Frizzy" mutants: A new class of aggregation-defective developmental mutants of Myxococcus xanthus. J. Bacteriol. 150: 1430-1437. 


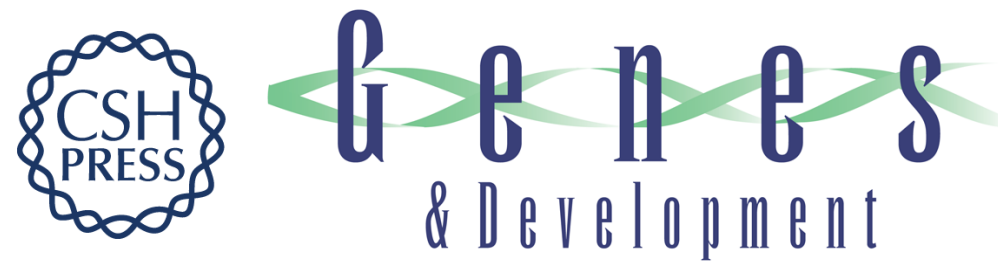

\section{Intercellular C-signaling in Myxococcus xanthus involves a branched signal transduction pathway.}

L Søgaard-Andersen, F J Slack, H Kimsey, et al.

Genes Dev. 1996, 10:

Access the most recent version at doi:10.1101/gad.10.6.740

References This article cites 55 articles, 36 of which can be accessed free at:

http://genesdev.cshlp.org/content/10/6/740.full.html\#ref-list-1

License

Email Alerting

Service

Receive free email alerts when new articles cite this article - sign up in the box at the top right corner of the article or click here.

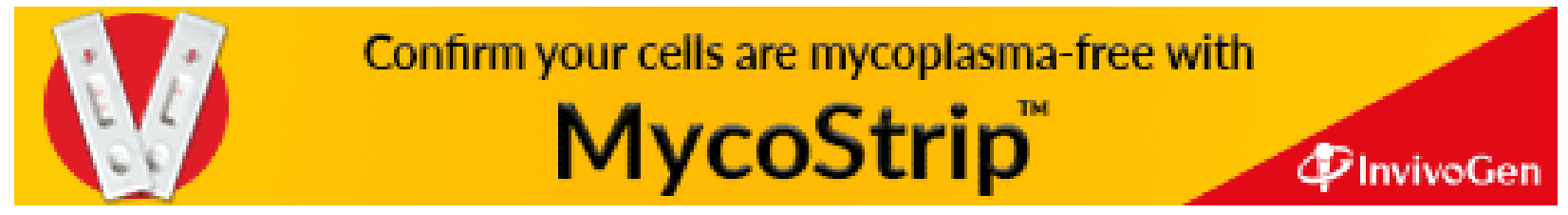

